Article

\title{
Allometric Models for Predicting Biomass and Carbon Pools of Boscia Senegalensis(Pers.) Lam. Ex Poir. (Capparaceae) Popula- tions in Central Africa: A Case Study from Cameroon
}

\author{
Djongmo Victor Awé ${ }^{1 *(-)}$, Noumi Valery Noiha ${ }^{2}$, Djomo Cédric Chimi ${ }^{3}{ }^{\complement}$, Moussa Ganamé ${ }^{4}$, Bi Tra Aimé \\ Vroh ${ }^{5}$, Louis Zapfack ${ }^{6}$
}

\author{
${ }^{1}$ Faculty of Sciences, University of Ngaoundere, Cameroon \\ ${ }^{2}$ Higher Teacher Training College of Bertoua, University of Ngaoundere, Cameroon \\ ${ }^{3}$ Institute of Agricultural Research for Development (IRAD) Bertoua Regional Research Center,Cameroon \\ ${ }^{4}$ Laboratory of Plant Biology and Ecology, University Joseph KI-ZERBO, Burkina Faso \\ ${ }^{5}$ UFR BioSciences,University Félix Houphouët-Boigny, Abidjan, Côte d'Ivoire \\ ${ }^{6}$ Faculty of Sciences, University of Yaounde I, Cameroon
}

*Correspondence: awevictor20@yahoo.fr

How to cite this paper : Awé, D. V., Noiha, N. V., Chimi, D. C., Ganamé, M., Vroh, B. T. A., \& Zapfack, L. (2021). Allometric Models for Predicting Biomass and Carbon Pools of Boscia Senegalensis(Pers.) Lam. Ex Poir. (Capparaceae) Popula-tions in Central Africa: A Case Study from Cameroon. Research Journal of Ecology and Environmental Sciences, 1(2), 123146. Retrieved from https://www.scipublications.com/journal/index.php/rjees/article/view/156

Received: September 17, 2021 Accepted: October 18, 2021 Published: October 19, 2021

Copyright: (c) 2021 by the authors. Submitted for possible open access publication under the Creative Commons Attribution (CC BY) license

(http://creativecommons.org/licenses /by/4.0/).

\begin{abstract}
Accurate estimates of above-ground biomass (AGB) and below-ground biomass (BGB) are essential for estimating carbon $(C)$ balances at various geographical scales and formulating effective climate change mitigation programs. This study aimed to formulate specific allometric equations and carbon stock for B. senegalensis in Cameroon. Destructive sampling technique was used for harvesting and weighing the biomass of 40 individual trees. Allometric models were developed using biomass as dependent variable and tree dendrometric parameters as independent variables. The best models selected based with Adjusted coefficients of determination (Adj. $\mathrm{R}^{2}$ ), residual standard error (RSE) and Akaike's information criterion (AIC) were: $\ln$ (leaf biomass) $=0.08+0.31^{*} \ln$ $\left(\mathrm{D}^{2} \times \mathrm{H} \times \mathrm{Q}\right) ; \ln ($ branch biomass $)=0.14+0.65^{*} \ln \left(\mathrm{D}^{2} \times \mathrm{H} \times \mathrm{Q}\right) ; \ln ($ stem biomass $)=2.03+1.32^{*} \ln \left(\mathrm{D}^{2} \times \mathrm{H}\right)$; $\ln (\mathrm{AGB})=4.55+2.85^{*} \ln (\mathrm{D})$ and $\ln (\mathrm{BGB})=3.04+1.64^{*} \ln (\mathrm{D})$. The belowground biomass of $B$. senegalensis represents on average $25 \%$ of the total aboveground biomass. Aboveground carbon ranged between $7.09 \pm 0.42-9.01 \pm 0.50 \mathrm{tC} / \mathrm{ha}$; Belowground carbon ranged between $4.37 \pm 0.26-7.11 \pm 0.35$ $\mathrm{tC} / \mathrm{ha}$; litter carbon ranged between $0.50 \pm 0.02-0.95 \pm 0.04 \mathrm{tC} / \mathrm{ha}$; herbaceous carbon ranged between $1.05 \pm 0.28-1.86 \pm 0.20 \mathrm{tC} / \mathrm{ha}$; dead wood carbon ranged between $3.03 \pm 0.40-8.98 \pm 0.44$ $\mathrm{tC} / \mathrm{ha}$; Soil Organic Carbon Stock varies between $4.33 \pm 0.79-6.14 \pm 1.05 \mathrm{tC} / \mathrm{ha}$;Total carbon were $33.24 \pm 4.28 ; 27.40 \pm 3.35 ; 27.27 \pm 3.27$ and $21.18 \pm 3.00 \mathrm{tC} /$ ha in site 3 , site 2 , site 1 and site 4 respectively.The specific allometric equation developed for $B$. senegalensis can be used in similar SudanoSahelian savannas to implement activities to reduce emissions from deforestation and degradation (REDD+) for the benefit of local carbon trading communities.
\end{abstract}

Keywords: Allometric models, Biomass, Boscia senegalensis, Carbon sinks

\section{Introduction}

Forest biomass is the main contributor to the global carbon cycle. It acts as a carbon source when burned and also as a sink when forests are conserved [1]. To mitigate global warming, an increase in forest cover is necessary to enhance carbon sinks, particularly in regions with low forest cover and increasing populations [2,3].Forests play a specific and important role in the global carbon-cycle, absorbing carbon dioxide during photosynthesis and storing it above and belowground [4]. The Reduction of Emissions from Deforestation and Forest Degradation (REDD+) projects are a political-effective option for the 
mitigation and adaptation to climate change. One of REDD+'s goals is to estimate the carbon reserves stored in the forests [5]. The existence of local allometric models to estimate biomass in different land uses is a fundamental part of the carbon inventories, and these are a basic requirement to develop forest projects for greenhouse gases (GHG) mitigation $[6,7,8]$.Forest biomass have been studied with different purposes, among which is the nutrient cycle, for energy purposes, in forest growth assessment, for forest management purposes, environmental impact mitigation [6,7]. Obtaining economic incentives for forest preservation and the reduction of such gases [5]. Since forest cover is the main carbon sink [4].

According to [9], a statistical relationship exists between the different measurements from an individual to a population scale. Thus, from the smallest to the largest, the proportions between diameter and the variables height, crown size and biomass obey a rule which is identical for all living trees under the same conditions [10]. He this is the basic principle of allometry, which allows you to predict the measurement of a tree (typically its biomass) according to other measurements such as for example the density of wood, diameter, total height, etc [10-12]. Thus, allometric equations are mathematical tools developed from direct measurements collected from trees and used to predict by the nondestructive method biomass or other measurements of other trees [13]. For [14], it is a formula /equation which quantitatively model the relationship between dendrometric parameters and the mass of the tree. [15], for their part, recommend that the relevance of the equations allometric is based on the fact that there is a relationship of proportionality between relative increases in the dimensions of an individual, for example biomass and diameter of a tree. However, this statistical relationship between biomass and the explanatory variables is only valid if this relationship has a biological reality, otherwise, its use could lead to sources of error in the estimate [16].

The diameter at breast height ( $\mathrm{dbh}$, in $\mathrm{cm})$, the wood density $\left(\mathrm{Q}\right.$, in ${\left.\mathrm{g} . \mathrm{cm}^{-3}\right)}^{-}$and the total height $(\mathrm{H}$, in $\mathrm{m})$ are explanatory variables of the most common allometric models commonly used for the development of allometric equations necessary for the prediction of the biomass of standing trees [15,17-27]. Some variables have recently been introduced in models such as the diameter of the crown [28] , the basal area of the tree[29] , and the climatic index noted "E" which takes into account the prevailing environmental conditions in a given environment[30].

These ecosystems are considered as a climate change mitigation strategy at global level [31]. Allometric models make easy to estimate volume and AGB from measuring easily measurable individual tree parameters such as diameter at breast height (dbh) and total tree height (ht) in forest inventories [31]. Another important explanatory variable for the estimation of biomass is wood basic density (WD). WD is determined from wood samples in laboratory as a ratio of dry mass to the green volume [31]. Literatures [32-37] list these variables according to their importance as dbh, WD, and ht in explaining tree biomass variations and $\mathrm{dbh}$ and $\mathrm{ht}$ for tree volume [32-37]. Among the three explanatory variables, tree $\mathrm{dbh}$ and $\mathrm{ht}$ have been often used as only explanatory variables to develop biomass allometric models [31].

Although allometric models exist for Africa $[35,36,37]$, these are generally limited in their applications by the dbh range used for the model calibration, uneven distribution of the dbh within the dbh range, the type and number of tree species used in developing the models, ecological zones, and the type and number of explanatory variables used [38]. Due to lack of local allometric models for some sub-Saharan African countries rely on pantropic models such as the ones developed by [30] for the estimation of local AGB and BGB. Although such pantropic models have a wide range of species from different ecological zones with wide calibration ranges, they are still not a panacea to the growing need for local allometric models across the continent. In view of this, more efforts are required to develop local allometric models for assessing tree carbon stock of forests to enable a better understanding of the contribution of local anthropogenic influence on atmospheric 
$\mathrm{CO}_{2}$ in Africa [39,40].The main objective of this study was to develop allometric models for accurate biomass estimation of Boscia senegalensis plantations. Further objective was to apply the allometric equations to derive the biomass stock of Boscia senegalensis plantation. The paper intends to test the hypothesis that the carbon storage potential of Boscia senegalensis plantation can play significant role in climate variability and change mitigation.

\section{Materials and Methods}

\subsection{Study area}

The study occurred in Central Africa, more precisely in Cameroon, in the North region of Cameroon. This region is located between $7.2^{\circ} \mathrm{N}$ to $9.99^{\circ} \mathrm{N}$ latitude and $12.6^{\circ}$ ' $\mathrm{E}$ to $15.3^{\circ} \mathrm{E}$ longitude (Figure 1)[4, 86,87]. The relief is a vast pedi-plain between the Mandara Mountains (1442 m) to the north and the Adamawa Plateau to the south[5].The climate is of the Sudano-Sahelian type with two seasons: a dry season lasting six months (November-May) and a rainy season lasting six months (June-October) [7,87]. The average monthly temperature varies from $26^{\circ} \mathrm{C}$ in August to $40^{\circ} \mathrm{C}$ in March (extreme temperatures: $17^{\circ} \mathrm{C}$ to $40^{\circ} \mathrm{C}$ ) [4]. The soil is of the ferruginous type characterized by acidity $(\mathrm{pH}=5.5$ to 6) and low cation exchange capacity [7]. The vegetation is a shrubby Sudano-sahelian savannah with a clear and degraded Savannah appearance around the villages [5]. Agriculture is the main activity of the people of the region. The population practices subsistence agriculture (corn, peanuts and millet) [5,87].The administrative North region of Cameroon comprises four subdivisions, namely, Bénoué, Faro, Mayo Louti, and Mayo Rey (Figure $1)$.

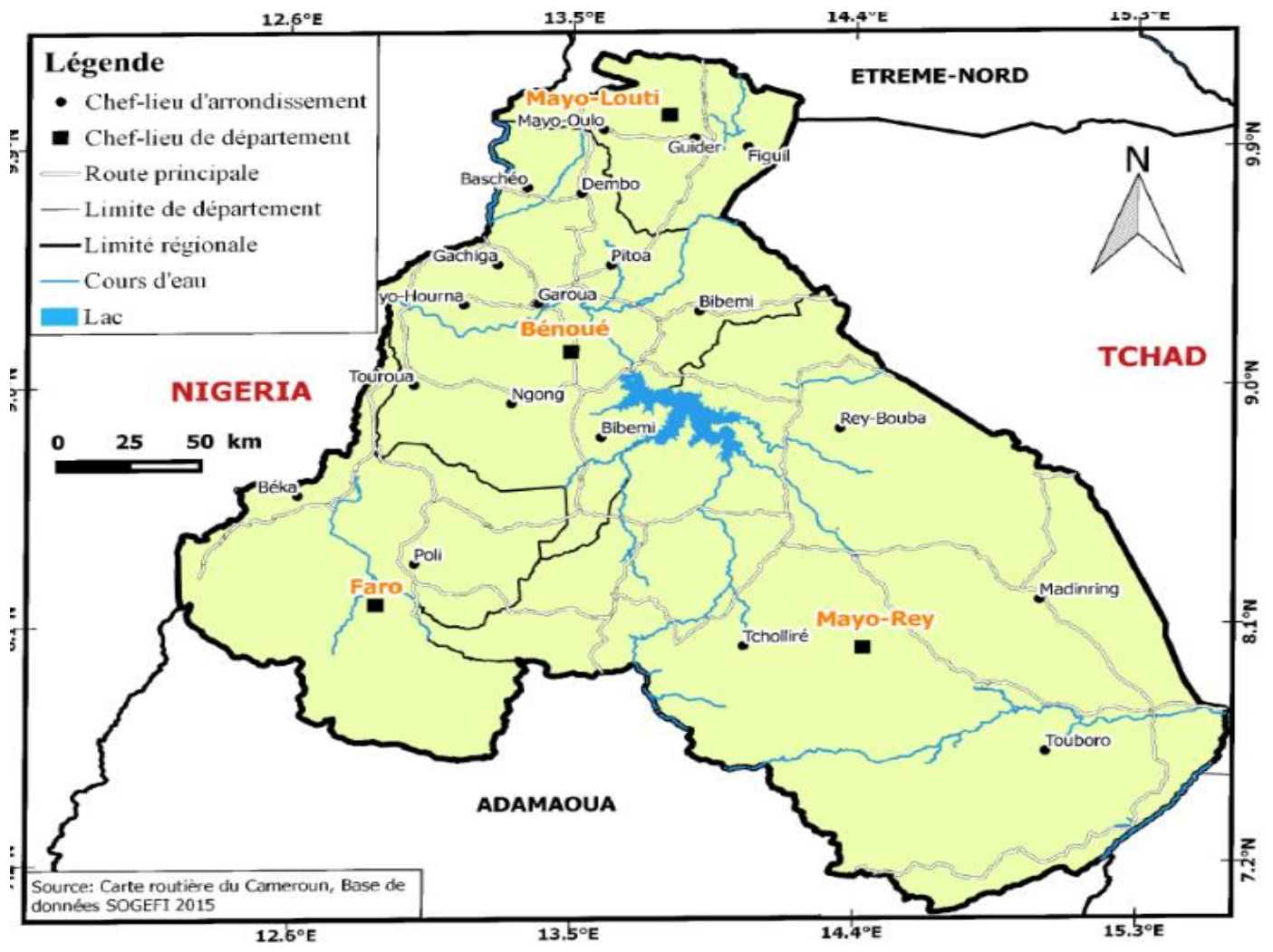

Figure 1. The geographic location of the study area in the North Region of Cameroon 


\subsection{Species description}

Boscia senegalensis is part of the Capparaceae family. Boscia senegalensis is a species from the Sahelian to Sudanese areas present on dry sites with rocky, lateritic, sandy soils (dunes) and on compact sandy-clay soils [41,42,43]. Its geographic area includes Burkina Faso, Cameroon, Côte d'Ivoire, Ethiopia, Mauritania, Mali, Nigeria, Niger, Senegal, Sudan and Chad [41,42,43]. Boscia senegalensis a shrub or shrub ranging from 1 to $8 \mathrm{~m}$ in height, Boscia senegalensis has an ovoid crown (Figure 2). Boscia senegalensis has leaves during the dry season, it has an oblique trunk and drooping branches. Its different parts are characterized as follows: Its bark is smooth with a dark gray color $[41,42,43]$. It has a slice of pinkish yellow or oronge color. The leaves of B. senegalensis are alternate, simple, and glabrous (sometimes pubescent) dark green above and light below, with pubescent petioles about 2 to $6 \mathrm{~mm}$ long and pinnate and reticulate veins [41,42,43]. Solitary (on young twigs) or sometimes grouped (on twigs over one-year-old), they are rigid and hard with varying sizes (on the same tree), with a length of 1.5 to $5 \mathrm{~cm}$ or 7 and a width of 1 to $2 \mathrm{~cm}[41,42,43]$. Oblong and lanceolate, their blades are obtuse at the top and wedge-shaped at the base. The Flowers are in short, dense clusters with a corymbic top forming a ball about $6 \mathrm{~cm}$ in diameter and have 4 sepals and 3 to 8 stamens [41,42,43]. Greenish-yellow or greenishwhite in color, they have a sweet odor. They appear during the cold season [41]. The fruits of $B$. senegalensis are round and/or sphere-shaped with a diameter of approximately 1 to 2 $\mathrm{cm}[41,42,43,44]$. Glabrous and rough, they are grouped in clusters and arranged on a support. They have a green color which turns yellow brown when ripe and have 1 to 2 seeds. Its twigs are pubescent at first, then glabrous. Lenticellate, they are gray-brown in color $[41,42]$.

Through its different parts, B. senegalensis has multiple and varied uses in medicine, food and cooking, agriculture and breeding and in industry and crafts $[45,46]$. B. senegalensis also has domestic uses $[41,42,46,47,48]$. In food and cooking: The leaves of $B$. senegalensis are edible and used as vegetables. The fruits (pulp) of B. senegalensis are edible. Walls they are eaten raw but immature they are eaten cooked $[45,46]$. Boiled $B$. senegalensis seeds can be used as a vegetable [45]. Also, dried these seeds give edible flour. In agriculture, pastoralism and animal health: The leaves of $B$. senegalensis are used as fodder for goats and sheep [45]. They are used as tonics in camels and horses in case of diarrhea [45,46]. They also drive away flies and fight colds and colds in horses and fever and trypanosomiasis in camels [45]. The fruits of $B$. senegalensis are purgative in camels. In industry, crafts and for domestic use: The leaves of $B$. senegalensis are used to protect cereals in granaries by hunting weevils and weevils [45]. Its roasted seeds serve as a substitute for coffee and to purify water [45]. In traditional and / or modern medicine: The bark of B. senegalensis is used to fight rheumatism and gastritis [45]. The leaves of $B$. senegalensis have an anthelmintic action and are used against rheumatism, stiffness, abscess, wounds, urticaria, ophthalmia, bilharzia, jaundice, gastritis, hemorrhoids, colic and neuralgia [45]. Associated with the twigs, they fight against asthenia and rheumatism $[45,49,50]$. The roots of $B$. senegalensis have an anthelmintic property and fight against impotence and gastritis. The fruits of $B$. senegalensis are a remedy for syphilis $[45,51]$. 


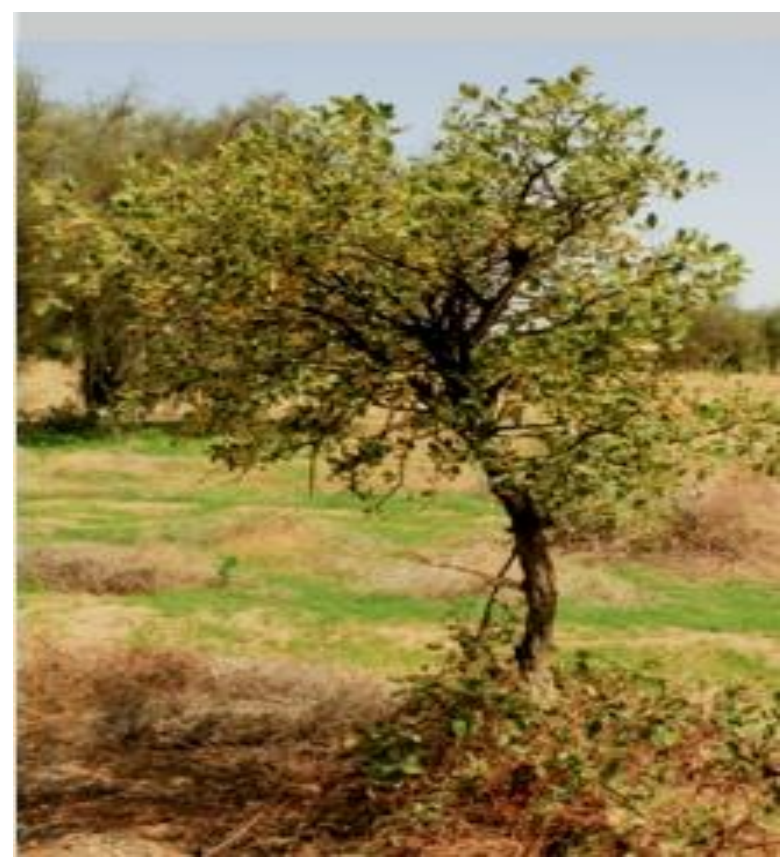

Figure 2. Individual of Boscia senegalensis

\subsection{Data collection}

\subsubsection{Models biomass sampling}

Forest inventory was conducted from April to July 2021. Destructive method was used to determine the biomass of each individual tree. Thus, 40 trees were harvested for estimating biomass and developing allometric models. Selection of each individual tree was based on diameter at breast height $(1.30 \mathrm{~m}$ aboveground). The individuals were grouped into five DBH classes: 0-5 cm, 5-10 cm, 10-15 cm, 15-20 cm, 20-25 cm. For each sample tree the DBH and total height $(\mathrm{H})$ of the stand trees were first recorded. Trees were felled close to ground level. The trees were selected to ensure a representative distribution of diameter classes within the sampling plots. Individuals were selected on the basis of their availability and the absence of human exploitation (traces of pruning or limping) or disease. Before the trees were felled, the diameters of the individuals with bark were determined using a tape and the total height was determined using a clinometer. The individuals were then cut $5 \mathrm{~cm}$ from the ground using a chainsaw and divided into compartments: the leaves; branches and trunks. The stems and large branches were cut into small pieces, and bagged and weighed with a scale in the field.

All 40 trees selected for destructive sampling were excavated for belowground tree component analysis. Once excavated, the main tree components were treated as by [52] as follows: (i) Root crown was cleaned to remove soil and weighed for green weight. (ii) All broken roots (roots not excavated) were measured for top diameter at breakage point on the root crown. Tap root was followed to the point where its diameter was nearly equal to the top diameter of the largest side root, and its weight was included to the weight of root crown. (iii) From each sample tree, 3 main roots (small, medium and big) were selected and traced to minimum diameter of $1 \mathrm{~cm}$. The top diameter and weight of each sample root were measured and recorded. When main roots enter obstacles (stone or another tree) the end point diameter was measured.

A sample from each compartment was taken and dried in an oven for 48 hours, at a temperature of $70{ }^{\circ} \mathrm{C}$ for the leaves and $105^{\circ} \mathrm{C}$ for the stem, branch discs. The water contents of the samples of leaves, branches and trunks will be calculated according to the following formula: 


$$
\mathrm{WC}(\%)=((\mathrm{WM}-\mathrm{DM}) / \mathrm{DM}) * 100
$$

Where: WC is the water content of the samples in percentage,

WM and DM are respectively the wet mass $(\mathrm{Kg})$ and the dry mass $(\mathrm{Kg})$ of the sample.

From the water content of the samples, the total dry masses of the fractions were calculated as follows:

$$
\operatorname{TDM}=100 * \mathrm{TWM} /(100+\mathrm{WC})
$$

Where: TDM is the total dry mass

TWM is the total wet mass $(\mathrm{Kg})$.

The total dry masses are called biomass and expressed in Kilograms (Kg).

The wood density of B. senegalensis was determined later by harvesting with a chainsaw a few pieces of wood from different parts of the stems and branches. These wood samples were immediately weighed to the ground using a sensitive balance. Subsequently, they were kept in bags, labeled and marked and from the part removed, placed in the shade and protected from heat in the laboratory. These wood samples were then soaked in water contained in a graduated cylinder, placed on a previously calibrated balance to finish determining the volume of wood [53]; all this with respect for Archimedes' principle. These samples were then dried in an oven at a constant temperature of $105^{\circ} \mathrm{C}$ [54] for about 72 hours depending on the plant material. From the third day of drying, each compartment was weighed every six hours using a very sensitive electric balance until a constant weight was obtained [55]. When the weight becomes constant, it is deduced while all the water contained in the material is totally evaporated. The data of each weighing has been saved. The density of the wood was obtained using the dry weight to volume ratio according to the formula of [53] below: $\mathrm{WDi}=\mathrm{DWi} / \mathrm{Vi}$; where $\mathrm{WD}$ is the wood density $i$, DWi the dry weight of species $i$ and Vi the volume of water of species.

\subsubsection{Sample Plots and Inventory Design}

Quadrats of $20 \mathrm{~m} \times 20 \mathrm{~m}$ were installed on four stands of B. senegalensis according to the criteria of densities, areas, topographies and each quadrat is spaced $5 \mathrm{~m}$ apart. A total of 25 quadrats were installed, for a total sampling area of 1 ha per site. Sampling bands were established using the compass, decameter, GPS and rope. At the ends of each strip, the stakes were planted at an equidistant distance of $20 \mathrm{~m}$. Along the quadrat, all woody plants with $\mathrm{Dbh}>5 \mathrm{~cm}$ were inventoried. Along the sub-quadrat, all the woody plants have been inventoried. All the trees were systematically counted and measured. The dendrometric data related to the measurement of dbh (Diameter at breast height) and total height were determined using a clinometer. Thus, the circumferences of the woody plants were measured using a tape measure at $1.30 \mathrm{~m}$ from the ground. The circumference values were then converted to diameter (dhp) according to the formula: $\mathrm{C}=\pi \mathrm{D}$, with $\mathrm{C}=$ circumference, $\mathrm{D}=$ diameter and $\pi=3.14$. To characterize the vegetation structure of the stands, the density and the basal area were calculated.

\subsubsection{Herbaceous and litter biomass}

The classical clear cut method was used for the quantification of herbaceous biomass. On each elementary plot $\left(400 \mathrm{~m}^{2}\right), 05$ frames of $1 \mathrm{~m} \times 1 \mathrm{~m}$ were installed for the collection of herbaceous plants using the secateurs. The herbaceous collection took place from MayAugust. A total of 5 samples were taken per $20 \mathrm{~m} \times 20 \mathrm{~m}$ boring unit, which corresponds to a total of 20 samples per stand. A total of 80 samples ( 4 site $\times 5$ samples $\times 4$ replicates $x$ 1 area) for the four sites studied. For the estimation of the carbon stock in the litter, about twenty square quadrats of $0.5 \times 0.5 \mathrm{~m}^{2}$ each, spaced $20 \mathrm{~m}$ from each other were installed randomly inside each site following the method of quadrats. The biomass of the litter is collected monthly from January-February. A total of 5 samples were taken per $20 \mathrm{~m} \times 20$ 
$\mathrm{m}$ boring unit, which corresponds to a total of 20 samples per site. A total of 80 samples (4 site $\times 5$ samples $\times 4$ replicates $\times 1$ area) for the four sites studied.

To determine the moisture content, the samples are returned quickly to the laboratory where they are reweighed, dried at $65^{\circ} \mathrm{C}$ to constant weight and then reweighed. The samples of litter and herbaceous plants dried in an oven at $65^{\circ} \mathrm{C}$ for 72 hours to constant weight, then reweighed and then ground for the determination of organic carbon by the calcinations method. The carbon was determined by incineration in an oven at $525^{\circ} \mathrm{C}$, after passing in an oven at $105^{\circ} \mathrm{C}$ for 48 hours.

\subsubsection{Deadwood biomass}

On each elementary plot $\left(400 \mathrm{~m}^{2}\right)$, strips of $20 \mathrm{~m} \times 20 \mathrm{~m}$ were installed for the collection of dead wood. In these bands, only dead wood in the interior was measured. Unmarked dead wood from outside the plot that fell inside it was not measured, while unmarked dead wood from inside the plot that is fallen outside of it was measured.

\subsubsection{Soil samples and laboratory analysis}

Soil samples are taken from December-January. In each $400 \mathrm{~m}^{2}$ survey, soil samples were taken in $0.25 \mathrm{~m} \times 0.25 \mathrm{~m}$ frames. These samples are taken at $0-10 \mathrm{~cm}, 10-20 \mathrm{~cm}, 20-30$ $\mathrm{cm}, 0-30 \mathrm{~cm}$ depths on the four elementary plots. Each depth of soil level was collected with a machete and trowel and then immediately put in a sealed bag in a cooler, in the shade to prevent evaporation. In total, 3 samples were taken per sampling unit, which corresponds to a total of 12 samples per site and then homogenized to obtain an aggregate sample. A total of 48 samples ( 4 site $\times 3$ depths $\times 4$ replicates $\times 1$ area) for the four sites studied, then were dug into the ground to a depth of $30 \mathrm{~cm}$. The organic carbon of the soil was determined by the method of Walkley \& Black [58] which is an oxidation with potassium bicarbonate $\left(\mathrm{K}_{2} \mathrm{Cr}_{2} \mathrm{O}_{7}\right)$ in an acidic medium $\left(\mathrm{H}_{2} \mathrm{SO}_{4}\right)$ according to NF ISO 14235 [59]. The assay was done by calorimetry. The organic matter content was obtained by multiplying the organic carbon rate by the Sprengel factor which is 1.724 for cultivated soils and 2 for non-cultivated soils.

The bulk density at the various research sites was determined by the cylinder method. It consists of taking a soil sample using a hollow metal cylinder of $100 \mathrm{~cm}^{3}$ volume. The soil extracted with the cylinder is levelled at the ends. The volume of soil removed is equal to that of the cylinder. The soil is then removed and dried at $105^{\circ} \mathrm{C}$ or 48 hours, it was weighed again.

Bulk density $(\mathrm{BD})=($ weight of dried soil-weight of empty cylinder)/ (Volume of the core) with $\mathrm{BD}\left(\mathrm{g} / \mathrm{cm}^{3}\right)$; weight of dried soil (g); empty cylinder (g); volume of the core $\left(\mathrm{cm}^{3}\right)$.

The granulometric analysis was carried out by the Robinson pipette method on airdried soil samples sieved at $2 \mathrm{~mm}$. The organic matter was previously destroyed by hydrogen peroxide attack. The soil was then dispersed by rotary agitation in flasks after the addition of sodium hexametaphosphate (NaPO3)6. The different particle size fractions were determined by pipetting for the clay and silt fractions and by sieving for the sand. The textural classes were found by using the FAO Textural Triangle, once the proportions of the different textural fractions were calculated.

\subsection{Data Analysis}

\subsubsection{Biomass equations}

Biomass equations using DBH, $\mathrm{H}$ and WD as the independent variable were developed and were regressed against the leaves, branches, stem, above and below ground Biomass allometric model of individual trees were derived from 40 sample trees in the North region of Cameroon. 
We first used the distance of Cook's residuals to identify outliers of explanatory and response variables [37]. We then examined the theoretical relationship between the response variable and the explanatory variables, testing the linear, logarithmic, exponential and power regression models. The response variable is the biomass expressed in $\mathrm{kg}$ and the explanatory variables are the diameter at breast height $(\mathrm{DBH})$ and tree height $(\mathrm{H})$. The best theoretical model retained to develop the equations for predicting the biomass of leaves, branches, stem, AGB and BGB of the tree for this species is the power model:

$$
\mathrm{B}=\mathrm{a} * \mathrm{Db}
$$

where $B$ is the biomass, $D$ is the diameter and, a and $b$, the coefficients of regression $[6,16$, 37].

The following models were considered for estimating Biomass ( $B, \mathrm{~kg}$ dry weight) from $\mathrm{DBH}, \mathrm{H}$ and WD where $a, b, c, d$ and e are coefficients $[13,15,21,22,23,25,28,30]$ :

$$
\begin{gathered}
\ln (\mathrm{B})=\mathrm{a}+\mathrm{b} \times \ln (\mathrm{D})(\text { Eq. } 1) \\
\ln (\mathrm{B})=\mathrm{a}+\mathrm{b} \times \ln (\mathrm{D} \times \mathrm{H})(\text { Eq. } 2) \\
\ln (\mathrm{B})=\mathrm{a}+\mathrm{b} \times \ln (\mathrm{D} \times \rho)(\text { Eq. 3) } \\
\ln (\mathrm{B})=\mathrm{a}+\mathrm{b} \times \ln \left(\mathrm{D}^{2} \times \mathrm{H}\right)(\text { Eq. } 4) \\
\ln (\mathrm{B})=\mathrm{a}+\mathrm{b} \times \ln \left(\mathrm{D}^{2} \times \rho\right)(\text { Eq. } 5) \\
\ln (\mathrm{B})=\mathrm{a}+\mathrm{b} \times \ln \left(\mathrm{D}^{2} \times \mathrm{H} \times \rho\right)(\text { Eq. } 6) \\
\ln (\mathrm{B})=\mathrm{a}+\mathrm{b} \times \ln \mathrm{D}+\mathrm{c} \times(\ln (\mathrm{D}))^{2}(\text { Eq. } 7) \\
\ln (\mathrm{B})=\mathrm{a}+\mathrm{b} \times \ln (\mathrm{D})+\mathrm{c} \times \ln (\rho)(\text { Eq. } 8) \\
\ln (\mathrm{B})=\mathrm{a}+\mathrm{b} \times \ln (\mathrm{D})+\mathrm{c} \times \ln (\mathrm{H})(\text { Eq. 9) } \\
\left.\ln (\mathrm{B})=\mathrm{a}+\mathrm{b} \times \ln \left(\mathrm{D}^{2} \times \mathrm{H}\right)+\mathrm{c} \times \ln (\rho)\right)(\text { Eq. 10) } \\
\ln (\mathrm{B})=\mathrm{a}+\mathrm{b} \times \ln \mathrm{D}+\mathrm{c} \times \ln \mathrm{H}+\mathrm{d} \times \ln (\rho)(\text { Eq. 11) } \\
\ln (\mathrm{B})=\mathrm{a}+\mathrm{b} \times \ln \mathrm{D}+\mathrm{c} \times \ln \mathrm{D}^{2}+\mathrm{d} \times \ln \mathrm{D}^{3}+\mathrm{e} \times \ln (\rho)(\text { Eq. 13) }
\end{gathered}
$$

The logarithmic transformation of the data generally leads to a bias in the estimation of Biomass [21, 37, 56]; a correction is therefore necessary and consists in multiplying the estimated Biomass by a correction factor (CF) which is calculated as follows:

$$
\mathrm{CF}=\exp \left(\mathrm{RSE}^{2} / 2\right)
$$

$\mathrm{CF}$ is a number always greater than 1 [23].

Three criteria were used to test the robustness and precision of the models in the estimation of above-ground biomass. They are in order of importance:

Adjusted coefficient of determination (Adjusted. $\mathrm{R}^{2}$ ).

AIC or Akaike Information Criterion obtained by the following formula:

$$
\mathrm{AIC}=-2 \ln (\mathrm{L})+2 \mathrm{p}
$$

(L "Likelihood" or Probability at which the predicted model is correct to the unknown true and p: Total number of parameters of the model) [57].

RSE or Residual standard error obtained by the following formula: 


$$
R S E=\sqrt{\frac{\sum\left(A G B_{o b s}-A G B_{\text {pred }}\right.}{n-2}}
$$

Where RSE: Residual standard error; AGB obs: Measured above-ground biomass; AGB pred: Predicted above-ground biomass, $n=$ data points in population.

Several goodness-of fit were combined to evaluate the developed allometrics models performance. Thus, the lowest residual standard error (RSE), Akaike information criterion (AIC), and the highest adjusted $\mathrm{R}^{2}$ values indicated the best models [16, 30].

Eventually, root to shoot ratio was calculated as ratio of below ground biomass to aboveground biomass.

$$
\mathrm{R}: \mathrm{S}=\mathrm{BGB} / \mathrm{AGB}
$$

Where; (R: S): Root to shoot ratio, BGB: Below ground biomass, AGB: Above ground biomass.

\subsubsection{Vegetation structure}

Density calculation

Densities (D) of individual trees were estimated using the formula according to [7]:

$$
\mathrm{D}=\mathrm{n} / \mathrm{S}
$$

Where $\mathrm{D}=$ Density (stems/ha), $\mathrm{n}=$ total number of individuals in a sample plot; $\mathrm{S}=$ area of the sample plot (ha).

Basal area calculation

The Basal area $(\mathrm{Ba})$ of individual trees was estimated using the formula according to [7]:

$$
B A=\frac{\pi}{4} D^{2}
$$

Where $\mathrm{Ba}=$ Basal area $\left(\mathrm{m}^{2}\right), \mathrm{D}=\mathrm{dbh}(\mathrm{cm})$ and $\pi=3.142$ (constant)

\subsubsection{Biomass and carbon stock estimation}

\subsubsection{Estimation of above (AGB) and below ground biomass (BGB)}

The determination of the amount of carbon present in the different components of the tree and in each plantation was made based on the allometric equations developed Table 4 according to the carbon stock models for the different tree components.

According to [83], the content of carbon in woody biomass of any forest is generally $50 \%$ of the tree total volume. Therefore, the weight of carbon in the tree was calculated by multiplying the dry weight of the tree by $50 \%$.

\subsubsection{Herbaceous and litter biomass}

$$
\mathrm{DM}=(\mathrm{DW} / \mathrm{WW}) * 100
$$

Where DM = Quantity of dry matter (\%); DW = dry weight of the sample after three days in the oven at $65^{\circ} \mathrm{C}(\mathrm{g}) ; \mathrm{WW}=$ wet weight of the sample measured in the field (g) [7].

$$
\mathrm{B}=(\mathrm{TWW} * \mathrm{DM}) / 100
$$

Where: $\mathrm{B}=$ biomass $(\mathrm{g})$; TWW = Total wet weight in measured in the field $(\mathrm{g})$; $\mathrm{DM}=$ percentage of dry matter $(\%)[7]$. 


\subsubsection{Dead wood biomass}

Calculating dead wood biomass was done using the formula used by[7,84] :

$$
\mathrm{V}=\pi^{2}\left(\Sigma \mathrm{di}^{2}\right) / 8 \mathrm{~L}
$$

Where dead wood biomass $\left(\mathrm{m}^{3} / \mathrm{ha}\right)$; Di: diameter of each wood debris sampled $(\mathrm{m})$; L: length of the quadrat $(m)=20 \mathrm{~m}$ in the case of our study.

Translating the results obtained from the bulk volume was made by setting the value of wood density to $0.47 \mathrm{KgMS} . \mathrm{m}^{-3[7,84]}$.

The portion of the dry mass of carbon stock is made by the following equation [7]:

$$
\text { DWCS }=(\mathrm{DM}) \times \mathrm{FC}(7)
$$

Where DWC= Dead wood carbon stock (tC/ha), DM= Quantity of dry matter $(\%)$; FC= Factor conversion $=0.5[7,84]$

\subsubsection{Soil organic carbon}

$$
\text { SOCS }=\% \mathrm{C} \times \mathrm{BD} \times \mathrm{d}
$$

Where: SOCS= Soil organic carbon stock per unit area $\left(\mathrm{tC} \cdot \mathrm{ha}^{-1}\right), \% \mathrm{C}=\mathrm{Carbon}$ concentration $(\%), \mathrm{d}=$ Soil depth $(\mathrm{cm})$, and BD: Bulk density $\left(\mathrm{g} . \mathrm{cm}^{-3}\right)$ [61].

\subsubsection{Total carbon}

$$
\mathrm{TC}=\mathrm{AGC}+\mathrm{BGC}+\mathrm{LC}+\mathrm{HC}+\mathrm{DWC}+\mathrm{SOCS}
$$

Where AGC $=$ Aboveground carbon stock $\left(\mathrm{tC} \cdot \mathrm{ha}^{-1}\right), \mathrm{BGC}=$ Belowground carbon stock $\left(\mathrm{tC}^{-} \mathrm{ha}^{-1}\right), \mathrm{LC}=$ Litter carbon stock $\left(\mathrm{tC} \cdot \mathrm{ha}^{-1}\right), \mathrm{HC}=$ Herbaceous carbon stock ( $\left.\mathrm{tC} \cdot \mathrm{ha}^{-1}\right)$, DWC $=$ Dead wood carbon stock $\left(\mathrm{tC}^{\mathrm{C}} \mathrm{ha}^{-1}\right), \mathrm{SOC}=$ Soil organic carbon stock $\left(\mathrm{tC} \cdot \mathrm{ha}^{-1}\right)$ and $\mathrm{TC}=$ Total carbon $\left(\mathrm{tC} \cdot \mathrm{ha}^{-1}\right)$.

\subsubsection{Atmospheric $\mathrm{CO}_{2}$ equivalent stock}

With regard to the sequestered atmospheric $\mathrm{CO}_{2}$ stock, it is recognized that the atomic mass of Carbon is 12 and the one Oxygen is 16. Consequently, the molecular mass of $\mathrm{CO}_{2}$ is 44 . Thus, the ratio of the combination of carbon $(\mathrm{C})$ and oxygen $\left(\mathrm{O}_{2}\right)$ is 3.67. The equivalent atmospheric $\mathrm{CO}_{2}$ stock $\left(\mathrm{VCO}_{2} \mathrm{eq}\right)$ is estimated by multiplying the carbon stock from biomass by 3.67 [7].

$$
\text { Atmospheric } \mathrm{CO}_{2} \text { equivalent stock }=\text { Total carbon } \times 3.67
$$

\subsection{Statistical analysis}

The data were encoded in EXCEL software and then analyzed using STATGRAPHICS plus 5.0 and R software. Analysis of variance (ANOVA) was used to test the existence or not of a significant difference in the difference parameters. Duncan test at 0.05 was used to compare parameter means.

\section{Results}

\subsection{Dendrometric characteristics and correlation between dendrometric parameters and biomass}

The average values of the diameter, height and wood density are $15.28 \mathrm{~cm}, 3.09 \mathrm{~m}$ and 0.58 g.cm ${ }^{-3}$ respectively (Table 1). Pearson's correlation showed that AGB and BGB are significantly correlated only with diameter, while leaves, branches biomass are significantly correlated with diameter, height and wood density. So the stem biomass was significantly correlated only with diameter and height (Table 2). 
Table 1. Dendrometric characteristics of sampled trees

\begin{tabular}{cccc}
\hline Item & DBH $(\mathrm{cm})$ & $\mathrm{H}(\mathrm{m})$ & WD or $\mathrm{Q}\left(\mathrm{g} \cdot \mathrm{cm}^{-3}\right)$ \\
\hline Minimum & 5.76 & 1.60 & 0.28 \\
maximum & 24.80 & 4.58 & 0.88 \\
Mean & 15.28 & 3.09 & 0.58 \\
\hline
\end{tabular}

Dbh: Diameter at Breast height, H: Height, WD or @: wood density.

Table 2. Correlation between Diameters (Dbh), Height $(\mathrm{H})$, wood density (WD) with Biomass

\begin{tabular}{cccc}
\hline Item & Dbh $(\mathrm{cm})$ & $\mathrm{H}(\mathrm{m})$ & WD or $\mathrm{Q}\left(\mathrm{g} \cdot \mathrm{cm}^{-3}\right)$ \\
\hline Leaves & $0.95^{* * *}$ & $0.88^{* * *}$ & $0.88^{* * *}$ \\
Branches & $0.90^{* * *}$ & $0.73^{* * *}$ & $0.73^{* * *}$ \\
stem & $0.87^{* * *}$ & $0.55^{*}$ & $0.28 \mathrm{~ns}$ \\
AGB & $0.96^{* * *}$ & $0.23 \mathrm{~ns}$ & $0.23 \mathrm{~ns}$ \\
BGB & $0.85^{* * *}$ & $0.35 \mathrm{~ns}$ & $0.35 \mathrm{~ns}$ \\
\hline
\end{tabular}

${ }^{*}$ : Significant, ${ }^{* *}$ : Very significant, ${ }^{* *}$ : Highly significant, ns: no significant

\subsection{Developed allometric equations}

Table 3 presents the allometric models developed for B. Senegalensis. The regression coefficients were statistically significant $(p<0.001)$ for all models. These coefficients varied between the same models developed in all compartments, with RSE and AIC ranging from $0.400-0.598 \mathrm{~kg}$ and $6.82-22.04 \mathrm{~kg}$ respectively, while their Adj. $\mathrm{R}^{2}$ varies from 0.44 0.97 (Table 3).

Table 3. Models parameters and performance criteria for biomass estimation

\begin{tabular}{|c|c|c|c|c|c|c|c|c|c|c|}
\hline \multirow{2}{*}{ Compartments } & \multirow{2}{*}{ Models } & \multicolumn{5}{|c|}{ Regressions coefficients } & \multirow{2}{*}{ Adj.R ${ }^{2}$} & \multirow{2}{*}{ RSE } & \multirow{2}{*}{ AIC } & \multirow{2}{*}{$\mathrm{FC}$} \\
\hline & & $\mathrm{a}$ & $\mathrm{b}$ & c & $\mathrm{d}$ & e & & & & \\
\hline \multirow{13}{*}{ Leaf } & 1 & $1.04^{* *}$ & $0.38^{* *}$ & & & & 0.75 & 0.445 & 8.75 & 1.10 \\
\hline & 2 & $0.52^{* * *}$ & $0.011^{*}$ & & & & 0.74 & 0.433 & 7.88 & 1.09 \\
\hline & 3 & $2.45^{* *}$ & $0.29^{* *}$ & & & & 0.76 & 0.487 & 7.98 & 1.12 \\
\hline & 4 & $0.82^{* * *}$ & $0.09^{* * *}$ & & & & 0.87 & 0.401 & 6.87 & 1.08 \\
\hline & 5 & $0.44^{* *}$ & $0.64^{* *}$ & & & & 0.85 & 0.445 & 10.01 & 1.10 \\
\hline & 6 & $0.08^{* * *}$ & $0.31^{*}$ & & & & 0.88 & 0.400 & 6.82 & 1.08 \\
\hline & 7 & $1.92^{* *}$ & $2.09^{* *}$ & $0.71^{* *}$ & & & 0.76 & 0.473 & 11.06 & 1.11 \\
\hline & 8 & $0.80^{* * *}$ & $2.02^{* * *}$ & $0.31^{* *}$ & & & 0.67 & 0.438 & 9.87 & 1.10 \\
\hline & 9 & $3.08^{* *}$ & $1.50^{* *}$ & $0.01^{* *}$ & & & 0.65 & 0.459 & 10.42 & 1.11 \\
\hline & 10 & $3.15^{* * *}$ & $1.11^{*}$ & $0.78^{* *}$ & & & 0.74 & 0.483 & 9.73 & 1.12 \\
\hline & 11 & $1.02^{* *}$ & $0.40^{* *}$ & $0.31^{* *}$ & $0.15^{* *}$ & & 0.76 & 0.487 & 7.96 & 1.12 \\
\hline & 12 & $3.21^{* * *}$ & $0.22^{* * *}$ & $0.10^{* *}$ & $0.82^{* *}$ & & 0.77 & 0.408 & 10.97 & 1.08 \\
\hline & 13 & $1.04^{* *}$ & $0.84^{* *}$ & $0.10^{* *}$ & $0.02^{* *}$ & $0.38^{* *}$ & 0.85 & 0.445 & 11.05 & 1.10 \\
\hline \multirow{4}{*}{ Branch } & 1 & $2.54^{* *}$ & $0.88^{* *}$ & & & & 0.73 & 0.425 & 10.04 & 1.09 \\
\hline & 2 & $0.92^{* * *}$ & $1.11^{*}$ & & & & 0.78 & 0.411 & 12.08 & 1.08 \\
\hline & 3 & $0.72^{* *}$ & $0.94^{* *}$ & & & & 0.83 & 0.438 & 10.41 & 1.10 \\
\hline & 4 & $0.53^{* * *}$ & $1.79^{* * *}$ & & & & 0.75 & 0.451 & 10.05 & 1.10 \\
\hline
\end{tabular}




\begin{tabular}{|c|c|c|c|c|c|c|c|c|c|c|}
\hline & 5 & $1.04^{* *}$ & \multicolumn{4}{|l|}{$0.49^{* *}$} & 0.84 & 0.409 & 9.88 & 1.08 \\
\hline & 6 & $0.14^{* * *}$ & \multicolumn{4}{|l|}{$0.65^{*}$} & 0.89 & 0.403 & 8.53 & 1.08 \\
\hline & 7 & $-0.03^{* *}$ & $-1.89^{* *}$ & \multicolumn{3}{|l|}{$0.61^{* *}$} & 0.77 & 0.418 & 10.07 & 1.09 \\
\hline & 8 & $0.40^{* * *}$ & $0.92^{* * *}$ & \multicolumn{3}{|l|}{$-0.01^{* *}$} & 0.74 & 0.415 & 8.97 & 1.08 \\
\hline & 9 & $3.08^{* *}$ & $0.50^{* *}$ & \multicolumn{3}{|l|}{$0.01^{* *}$} & 0.84 & 0.411 & 10.24 & 1.08 \\
\hline & 10 & $0.15^{* * *}$ & $-0.11^{*}$ & \multicolumn{3}{|l|}{$-0.08^{* *}$} & 0.71 & 0.417 & 9.05 & 1.09 \\
\hline & 11 & $1.02^{* * *}$ & $0.40^{* *}$ & $0.31^{* *}$ & \multicolumn{2}{|l|}{$0.15^{* *}$} & 0.82 & 0.418 & 10.00 & 1.09 \\
\hline & 12 & $-0.88^{* * *}$ & $0.02^{* * *}$ & $-0.10^{* *}$ & \multicolumn{2}{|l|}{$0.82^{* *}$} & 0.68 & 0.415 & 10.11 & 1.08 \\
\hline & 13 & $-2.94^{* *}$ & $0.33^{* *}$ & $0.10^{* *}$ & $0.02^{* *}$ & $0.08^{* *}$ & 0.76 & 0.423 & 10.94 & 1.09 \\
\hline \multirow{13}{*}{ Stem } & 1 & $0.04^{* *}$ & $-1.88^{* *}$ & & & & 0.86 & 0.487 & 9.70 & 1.12 \\
\hline & 2 & $-0.30^{* * *}$ & $2.81^{*}$ & & & & 0.87 & 0.426 & 10.07 & 1.09 \\
\hline & 3 & $-2.72^{* *}$ & $0.04^{* *}$ & & & & 0.85 & 0.445 & 10.00 & 1.10 \\
\hline & 4 & $2.03^{* * *}$ & $1.32^{* * *}$ & & & & 0.95 & 0.401 & 8.04 & 1.08 \\
\hline & 5 & $-5.04^{* *}$ & $0.98^{* *}$ & & & & 0.86 & 0.412 & 9.06 & 1.08 \\
\hline & 6 & $0.47^{* * *}$ & $-5.65^{*}$ & & & & 0.88 & 0.421 & 10.07 & 1.09 \\
\hline & 7 & $-6.03^{* *}$ & $-1.05^{* *}$ & \multicolumn{3}{|l|}{$-6.61^{* *}$} & 0.80 & 0.407 & 9.76 & 1.08 \\
\hline & 8 & $-7.40^{* * *}$ & $2.92^{* * *}$ & \multicolumn{3}{|l|}{$-0.81^{* *}$} & 0.90 & 0.428 & 10.89 & 1.09 \\
\hline & 9 & $0.08^{* *}$ & $-0.90^{* *}$ & \multicolumn{3}{|l|}{$0.31^{* *}$} & 0.83 & 0.415 & 11.01 & 1.08 \\
\hline & 10 & $-3.15^{* * *}$ & $-0.11^{*}$ & \multicolumn{3}{|l|}{$-0.08^{* *}$} & 0.91 & 0.403 & 10.48 & 1.08 \\
\hline & 11 & $0.92^{* *}$ & $-7.40^{* *}$ & $0.01^{* *}$ & \multicolumn{2}{|l|}{$0.75^{* *}$} & 0.86 & 0.407 & 9.03 & 1.08 \\
\hline & 12 & $-4.01^{* * *}$ & $0.23^{* * *}$ & $-0.43^{* *}$ & \multicolumn{2}{|l|}{$0.01^{* *}$} & 0.93 & 0.418 & 10.99 & 1.09 \\
\hline & 13 & $2.04^{* *}$ & $-0.54^{* *}$ & $-1.19^{* *}$ & $0.22^{* *}$ & $0.07^{* *}$ & 0.76 & 0.405 & 13.03 & 1.08 \\
\hline \multirow{13}{*}{ AGB } & 1 & $4.55^{* *}$ & $2.85^{* *}$ & & & & 0.97 & 0.408 & 10.07 & 1.08 \\
\hline & 2 & $2.92^{* * *}$ & $-4.11^{*}$ & & & & 0.85 & 0.445 & 10.65 & 1.10 \\
\hline & 3 & $0.72^{* * *}$ & $0.94^{* *}$ & & & & 0.94 & 0.433 & 10.94 & 1.09 \\
\hline & 4 & $-4.53^{* * *}$ & $0.09^{* * *}$ & & & & 0.76 & 0.487 & 10.76 & 1.12 \\
\hline & 5 & $-2.04^{* *}$ & $0.01^{* *}$ & & & & 0.87 & 0.468 & 10.57 & 1.11 \\
\hline & 6 & $0.14^{* * *}$ & $-0.05^{*}$ & & & & 0.86 & 0.487 & 10.76 & 1.12 \\
\hline & 7 & $-5.03^{* * *}$ & $-1.00^{* *}$ & \multicolumn{3}{|l|}{$1.01^{* *}$} & 0.80 & 0.438 & 10.85 & 1.10 \\
\hline & 8 & $2.00^{* * *}$ & $-6.92^{* * *}$ & \multicolumn{3}{|l|}{$-0.98^{* *}$} & 0.65 & 0.445 & 10.65 & 1.10 \\
\hline & 9 & $-7.33^{* *}$ & $0.77^{* *}$ & \multicolumn{3}{|l|}{$0.63^{* *}$} & 0.93 & 0.431 & 10.94 & 1.09 \\
\hline & 10 & $0.05^{* * *}$ & $-8.02^{*}$ & \multicolumn{3}{|l|}{$2.06^{* *}$} & 0.78 & 0.480 & 10.70 & 1.12 \\
\hline & 11 & $1.09^{* *}$ & $-0.80^{* *}$ & $2.31^{* *}$ & \multicolumn{2}{|l|}{$-6.50^{* *}$} & 0.67 & 0.452 & 10.63 & 1.10 \\
\hline & 12 & $-3.08^{* * *}$ & $1.11^{* * *}$ & $0.76^{* *}$ & \multicolumn{2}{|l|}{$1.02^{* *}$} & 0.77 & 0.489 & 10.36 & 1.12 \\
\hline & 13 & $1.31^{* *}$ & $0.03^{* *}$ & $-2.18^{* *}$ & $0.58^{* *}$ & $0.12^{* *}$ & 0.91 & 0.422 & 10.15 & 1.09 \\
\hline \multirow{6}{*}{ BGB } & 1 & $3.04^{* *}$ & $1.64^{* *}$ & & & & 0.85 & 0.500 & 8.05 & 1.13 \\
\hline & 2 & $0.92^{* * *}$ & $1.11^{*}$ & & & & 0.44 & 0.598 & 22.04 & 1.19 \\
\hline & 3 & $0.72^{* *}$ & $0.94^{* *}$ & & & & 0.73 & 0.587 & 20.90 & 1.18 \\
\hline & 4 & $0.53^{* * *}$ & $1.79^{* * *}$ & & & & 0.47 & 0.508 & 10.07 & 1.13 \\
\hline & 5 & $1.04^{* *}$ & $0.49^{* *}$ & & & & 0.50 & 0.567 & 19.03 & 1.17 \\
\hline & 6 & $0.14^{* * *}$ & $0.65^{*}$ & & & & 0.57 & 0.518 & 10.07 & 1.14 \\
\hline
\end{tabular}




\begin{tabular}{|c|c|c|c|c|c|c|c|c|}
\hline 7 & $-0.03^{* *}$ & $-1.89^{* *}$ & $0.61^{* *}$ & & & 0.65 & 0.525 & 11.65 \\
\hline 8 & $0.40^{* * *}$ & $0.92^{* * *}$ & $-0.01^{* *}$ & & & 0.64 & 0.503 & 11.44 \\
\hline 9 & $3.08^{* *}$ & $0.50^{* *}$ & $0.01^{* *}$ & & & 0.80 & 0.557 & 18.32 \\
\hline 10 & $0.15^{* * *}$ & $-0.11^{*}$ & $-0.08^{* *}$ & & & 0.67 & 0.508 & 10.07 \\
\hline 11 & $1.02^{* *}$ & $0.40^{* * *}$ & $0.31^{* *}$ & $0.15^{* *}$ & & 0.76 & 0.527 & 10.76 \\
\hline 12 & $-0.88^{* * *}$ & $0.02^{* * *}$ & $-0.10^{* *}$ & $0.82^{* *}$ & & 0.70 & 0.528 & 10.07 \\
\hline 13 & $-2.94^{* *}$ & $0.33^{* *}$ & $0.10^{* *}$ & $0.02^{* *}$ & $0.08^{* *}$ & 0.75 & 0.525 & 10.65 \\
\hline
\end{tabular}

The coefficients at $p<0.001$ are significantly different from zero; ${ }^{*}$ : Significant, ${ }^{* *}$ : Very significant, ***: Highly significant, AGB: Aboveground biomass, BGB: Belowground biomass, D: Diameter, H: Height, WD: Wood density, Coefficient of regression model (a, b, c, d and e), coefficient of determination adjusted (Adj.R²), correction factor (CF), residual standard error (RSE) and Akaike information criteria (AIC).

\subsection{Best Models selected across}

Predicted parameters varied between tree compartments. DBH accurately predicted the AGB and BGB (Table 4). Stem biomass were better predicted with $\mathrm{D}^{2} \times \mathrm{h}$ (Table 4). The leaves and branches biomasses were better predicted with $\mathrm{D}^{2} \times \mathrm{H} \times \mathrm{Q}$. These best equations are shown in Table 4 and Figure 3 shows their adjustments.

Table 4. Selection of the Best Models

\begin{tabular}{ccccc}
\hline Models & Adj.R & RSE & AIC & CF \\
\hline $\ln ($ leaf biomass $)=0.08+0.31^{*} \ln \left(\mathrm{D}^{2} \times \mathrm{H} \times \mathrm{Q}\right)$ & 0.88 & 0.400 & 6.82 & 1.08 \\
$\ln ($ branch biomass $)=0.14+0.65^{*} \ln \left(\mathrm{D}^{2} \times \mathrm{H} \times \mathrm{Q}\right)$ & 0.89 & 0.403 & 8.53 & 1.08 \\
$\ln ($ stem biomass $)=2.03+1.32^{*} \ln \left(\mathrm{D}^{2} \times \mathrm{H}\right)$ & 0.95 & 0.401 & 8.04 & 1.08 \\
$\ln (\mathrm{AGB})=4.55+2.85^{*} \ln (\mathrm{D})$ & 0.97 & 0.408 & 10.07 & 1.08 \\
$\ln (\mathrm{BGB})=3.04+1.64^{*} \ln (\mathrm{D})$ & 0.85 & 0.500 & 8.05 & 1.13 \\
\hline
\end{tabular}

AGB: Aboveground biomass, BGB: Belowground biomass, ln: logarithmic, D: Diameter, H: Height,Q: wood density, Coefficient of determination adjusted (Adj.R $\left.{ }^{2}\right)$, residual standard error (RSE) and Akaike information criteria (AIC). 

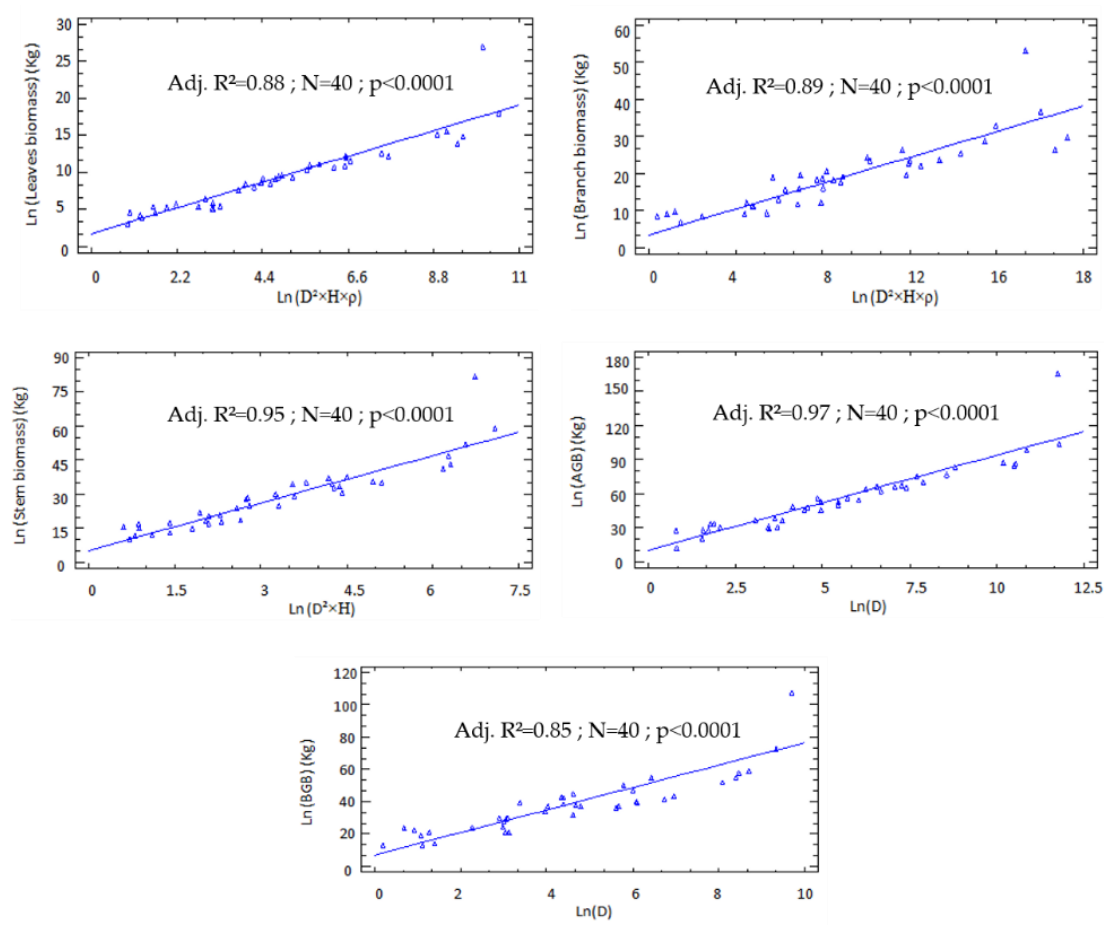

Figure 3. Linear regressions between parameter (D, H and @) with leaves biomass (a), branch biomass (b), stem biomass (c), aboveground biomass (AGB) (d) and belowground biomass (BGB) (e)

\subsection{Ratios between belowground Biomass, Biomass from other above-ground compartments and Total aboveground Biomass}

The average ratios of root biomass to other parts of the tree (ratio) were evaluated (Table 5). The average ratio of root biomass to other tree components ranges from 0.25 to 1.88. However, the most important biomass in the estimates is the total biomass (Table 5).

Table 5. Average ratios according to the compartments

\begin{tabular}{ccccc}
\hline Ratios & BGB /LB & BGB /BB & BGB/SB & BGB /TAGB \\
\cline { 2 - 5 } Mean (STD) & $1.88(0.83)$ & $0.68(0.32)$ & $0.66(0.21)$ & $0.25(0.12)$ \\
\hline
\end{tabular}

BGB: Belowground biomass, LB: Leaves biomass, BB: Branch Biomass, SB: Stem biomass, TAGB: Total Aboveground biomass, STD: Standard deviation.

\subsection{Root-shoot ratio}

The calculated root / stems ratio (R:S), for all samples of B. senegalensis destroyed had the overall mean of 0.24 , for all diameter classes. In addition, the trend shows that, R: S, increases with increasing diameter class rate, and tend to decrease at a diameter of 15-20 $\mathrm{cm}$ to $20-25 \mathrm{~cm}$ (Table 6). The calculated R: S varies significantly in all the classes of Dbh $(\mathrm{p}<0.05)$. 
Table 6. Root shoot ratio

\begin{tabular}{cccccc}
\cline { 2 - 6 } & \multicolumn{5}{c}{ R:S Ratio } \\
\hline Variables Dbh class $(\mathrm{cm})$ & $\mathrm{n}$ & mean & minimum & $\begin{array}{c}\text { maxi- } \\
\text { mum }\end{array}$ & Standard deviation \\
\hline $0-5 \mathrm{~cm}$ & 5 & $0.23 \mathrm{ab}$ & 0.05 & 0.41 & 0.02 \\
$5-10 \mathrm{~cm}$ & 9 & $0.26 \mathrm{~b}$ & 0.08 & 0.45 & 0.03 \\
$10-15 \mathrm{~cm}$ & 11 & $0.34 \mathrm{c}$ & 0.04 & 0.65 & 0.04 \\
$15-20 \mathrm{~cm}$ & 15 & $0.20 \mathrm{ab}$ & 0.02 & 0.38 & 0.02 \\
$20-25 \mathrm{~cm}$ & 20 & $0.17 \mathrm{a}$ & 0.09 & 0.25 & 0.01 \\
\hline
\end{tabular}

Between the columns, Values assigned the same letter are not statistically different ( $p>0.05$; Duncan's test)

The difference in rainfall could explain the rooting in the two types of soil. In areas with insufficient rainfall, species tend to develop deep rooting [14,15].

\subsection{Vegetation structure}

The average density of four sites is $335.75 \pm 25.89$ individuals / ha. The highest density was recorded in site 4 (535 \pm 41.85 individuals / ha). The analysis of variance shows that there is a significant difference in density between the four sampled sites $(p<0.05)$ (Table 7).

The mean basal area of four sites is $5.77 \pm 1.16 \mathrm{~m}^{2} /$ ha. The highest basal area was recorded in site $3\left(10.88 \pm 2.62 \mathrm{~m}^{2} / \mathrm{ha}\right)$. Analysis of variance shows that there is a significant difference in basal area between the four sampled sites $(p<0.05)$ (Table 7$)$.

Table 7. Density and basal area in the four sites

\begin{tabular}{ccc}
\hline Sites & Density (individuals/ha) & Basal area $\left(\mathrm{m}^{2} / \mathrm{ha}\right)$ \\
\hline Site 1 & $395 \pm 30.05 \mathrm{c}$ & $3.93 \pm 0.65 \mathrm{~b}$ \\
Site 2 & $285 \pm 21.02 \mathrm{~b}$ & $5.55 \pm 1.05 \mathrm{c}$ \\
Site 3 & $128 \pm 10.65 \mathrm{a}$ & $10.88 \pm 2.62 \mathrm{~d}$ \\
Site 4 & $535 \pm 41.85 \mathrm{~d}$ & $2.74 \pm 0.35 \mathrm{a}$ \\
\hline Mean & $335.75 \pm 25.89$ & $5.77 \pm 1.16$ \\
\hline
\end{tabular}

Between the columns, Values assigned the same letter are not statistically different ( $p>0.05$; Duncan's test)

\subsection{Estimation of Carbon stock}

\subsubsection{Carbon pools}

The Aboveground carbon vary from $7.09 \pm 0.42-9.01 \pm 0.50 \mathrm{tC} /$ ha with a higher value in site 3 . The analysis of variance does not show a significant difference in the aboveground carbon between the four sites studied $(\mathrm{F}=0.05 ; \mathrm{P}=0.53>0.05)$ (Table 8$)$.

Table 8. Estimation of Carbon pools for compartments within sites

\begin{tabular}{cccccccc}
\hline \multirow{2}{*}{ Sites } & \multicolumn{5}{c}{ Aboveground } & \multicolumn{2}{c}{ Belowground } \\
\cline { 2 - 8 } Site 1 & Leaf(t/ha) & Branch(t/ha) & Stem $(\mathrm{t} / \mathrm{ha})$ & TAGB $(\mathrm{t} / \mathrm{ha})$ & AGC $(\mathrm{tC} / \mathrm{ha})$ & BGB $(\mathrm{t} / \mathrm{ha})$ & BGC $(\mathrm{tC} / \mathrm{ha})$ \\
\cline { 2 - 8 } Site 2 & $3.54 \pm 0.11 \mathrm{a}$ & $4.87 \pm 0.27 \mathrm{a}$ & $7.87 \pm 0.39 \mathrm{a}$ & $15.28 \pm 2.98 \mathrm{a}$ & $7.64 \pm 0.42 \mathrm{a}$ & $9.45 \pm 1.42 \mathrm{a}$ & $4.72 \pm 0.28 \mathrm{a}$ \\
Site 3 & $4.79 \pm 0.25 \mathrm{a}$ & $8.87 \pm 0.43 \mathrm{a}$ & $17.53 \pm 3.10 \mathrm{a}$ & $8.76 \pm 0.45 \mathrm{a}$ & $10.83 \pm 1.45 \mathrm{a}$ & $5.41 \pm 0.30 \mathrm{a}$ \\
Site 4 & $2.09 \pm 0.14 \mathrm{a}$ & $5.05 \pm 0.28 \mathrm{a}$ & $8.98 \pm 0.44 \mathrm{a}$ & $18.03 \pm 3.12 \mathrm{a}$ & $9.01 \pm 0.50 \mathrm{a}$ & $14.22 \pm 1.50 \mathrm{a}$ & $7.11 \pm 0.35 \mathrm{a}$ \\
Mean & $3.56 \pm 0.20 \mathrm{a}$ & $7.54 \pm 0.40 \mathrm{a}$ & $14.19 \pm 2.90 \mathrm{a}$ & $7.09 \pm 0.42 \mathrm{a}$ & $8.74 \pm 1.42 \mathrm{a}$ & $4.37 \pm 0.26 \mathrm{a}$ \\
\hline
\end{tabular}


Aboveground biomass (AGB), belowground biomass (BGB), Aboveground Carbon contents (AGC) and belowground Carbon contents (BGC). Between the columns, values assigned the same letter are not statistically different $(\mathrm{p}>0.05$; Duncan's test)

The belowground carbon vary from $4.37 \pm 0.26-7.11 \pm 0.35 \mathrm{tC} /$ ha with a higher value in site 3. Analysis of variance does not show a significant difference in the belowground carbon between the four sites studied $(\mathrm{F}=0.08 ; \mathrm{P}=0.62>0.05)$ (Table 8).

The litter carbon vary from $0.50 \pm 0.02-0.95 \pm 0.04 \mathrm{tC} /$ ha with a higher value in site 3 . The analysis of variance does not show a significant difference in the litter carbon between the four sites studied $(\mathrm{F}=0.38 ; \mathrm{P}=0.298>0.05)$ (Table 9).

Table 9. Estimation of Carbon litter, herbaceous and dead wood within sites

\begin{tabular}{cccc}
\hline Sites & $\mathrm{LC}(\mathrm{t} / \mathrm{ha})$ & $\mathrm{HC}(\mathrm{t} / \mathrm{ha})$ & $\mathrm{DWC}(\mathrm{t} / \mathrm{ha})$ \\
\hline Site 1 & $0.65 \pm 0.01 \mathrm{a}$ & $1.80 \pm 0.27 \mathrm{a}$ & $7.65 \pm 0.39 \mathrm{c}$ \\
Site 2 & $0.87 \pm 0.03 \mathrm{a}$ & $1.69 \pm 0.25 \mathrm{a}$ & $5.87 \pm 0.43 \mathrm{~b}$ \\
Site 3 & $0.95 \pm 0.04 \mathrm{a}$ & $1.05 \pm 0.28 \mathrm{a}$ & $8.98 \pm 0.44 \mathrm{a}$ \\
Site 4 & $0.50 \pm 0.02 \mathrm{a}$ & $1.86 \pm 0.20 \mathrm{a}$ & $3.03 \pm 0.40 \mathrm{~d}$ \\
Mean & $0.74 \pm 0.02$ & $1.60 \pm 0.25$ & $6.63 \pm 0.41$ \\
\hline
\end{tabular}

Litter Carbon (LC), herbaceous Carbon (HC), dead wood Carbon (DWC). Between the columns, values assigned the same letter are not statistically different ( $\mathrm{p}>0.05$; Duncan's test)

The herbaceous carbon vary from $1.05 \pm 0.28-1.86 \pm 0.20 \mathrm{tC} /$ ha with a higher value in site 4 . The analysis of variance does not show a significant difference in the herbaceous carbon between the four sites studied $(\mathrm{F}=0.104 ; \mathrm{P}=0.105>0.05)$ (Table 9).

The dead wood carbon vary from $3.03 \pm 0.40-8.98 \pm 0.44 \mathrm{tC} /$ ha with a higher value in site 3 . The analysis of variance does not show a significant difference in the dead wood carbon between the four sites studied ( $\mathrm{F}=0.098 ; \mathrm{P}=0.25>0.05)$ (Table 9).

\subsubsection{Soil Physical Characteristics}

The Bulk densities vary between sites. The highest value is recorded in site $1(1.60 \pm$ $0.02 \mathrm{~g} / \mathrm{cm}^{3}$ ). The analysis of variance does not show a significant difference in the Bulk density between the four sites studied $(\mathrm{F}=0.03 ; \mathrm{P}=0.563>0.05)$ (Table 10).

Table 10. Variation in bulk density as a function of depth under different sites

\begin{tabular}{ccccc}
\hline Depth $(\mathrm{cm})$ & Site 1 & Site 2 & Site 3 & Site 4 \\
\cline { 2 - 5 } $0-10$ & $1.64 \pm 0.02 \mathrm{a}$ & $1.06 \pm 0.00 \mathrm{a}$ & $1.31 \pm 0.01 \mathrm{a}$ & $1.49 \pm 0.02 \mathrm{a}$ \\
$10-20$ & $1.45 \pm 0.01 \mathrm{a}$ & $1.63 \pm 0.03 \mathrm{a}$ & $1.22 \pm 0.00 \mathrm{a}$ & $1.34 \pm 0.01 \mathrm{a}$ \\
$20-30$ & $1.72 \pm 0.03 \mathrm{a}$ & $1.41 \pm 0.02 \mathrm{a}$ & $1.35 \pm 0.02 \mathrm{a}$ & $1.65 \pm 0.04 \mathrm{a}$ \\
\hline Mean & $1.60 \pm 0.02$ & $1.36 \pm 0.01$ & $1.29 \pm 0.01$ & $1.49 \pm 0.02$ \\
\hline
\end{tabular}

Between the columns, values assigned the same letter are not statistically different ( $p>0.05$; Duncan's test)

The granulometry distribution made it possible to distinguish 2 textural classes including sandy and sandy clay. The soils studied are predominantly sandy. Data analysis for the textural fractions of the soils (Clay: P-value $=0.068$; Silt: Pvalue $=0.078$ and Sand: $\mathrm{P}$-value $=0.084$ ) show that there is a variation in the textural composition of the soils at different depths between the four sites studied (Table 11). 
Table 11. Soil texture under the different sites

\begin{tabular}{ccccc}
\hline Textural fractions & Site 1 & Site 2 & Site 3 & Site 4 \\
\hline$\%$ Sand & $48 \pm 5.50 \mathrm{~b}$ & $88 \pm 9.52 \mathrm{~b}$ & $50 \pm 5.75 \mathrm{c}$ & $45 \pm 5.03 \mathrm{~b}$ \\
$\%$ Silt & $12 \pm 1.54 \mathrm{a}$ & $5 \pm 1.51 \mathrm{a}$ & $10 \pm 2.05 \mathrm{a}$ & $14 \pm 2.10 \mathrm{a}$ \\
$\%$ Clay & $40 \pm 5.48 \mathrm{~b}$ & $7 \pm 1.76 \mathrm{a}$ & $40 \pm 4.43 \mathrm{~b}$ & $41 \pm 5.00 \mathrm{~b}$ \\
\hline Textural classes & Sandy clay & Sandy & Sandy clay & Sandy clay \\
\hline
\end{tabular}

Between the columns, values assigned the same letter are not statistically different ( $p>0.05$; Duncan's test)

\subsubsection{Soil organic carbon stock}

The Soil Organic Carbon Stock varies between sites. The highest value is recorded in site $3(6.14 \pm 1.05 \mathrm{tC} / \mathrm{ha})$. The analysis of variance does not show a significant difference in the Soil Organic Carbon Stock between the four sites studied $(\mathrm{F}=0.085 ; \mathrm{P}=0.38>0.05)$ (Table 12).

Table 12. Estimation of SOC within sites

\begin{tabular}{ccccc}
\hline sites & $0-10 \mathrm{~cm}$ & $10-20 \mathrm{~cm}$ & $20-30 \mathrm{~cm}$ & Total $(0-30 \mathrm{~cm})$ \\
\hline Site 1 & $2.64 \pm 0.38 \mathrm{a}$ & $1.45 \pm 0.30 \mathrm{a}$ & $0.72 \pm 0.19 \mathrm{a}$ & $4.81 \pm 0.84 \mathrm{a}$ \\
Site 2 & $1.76 \pm 0.34 \mathrm{a}$ & $1.63 \pm 0.35 \mathrm{a}$ & $1.41 \pm 0.28 \mathrm{a}$ & $4.80 \pm 0.80 \mathrm{a}$ \\
Site 3 & $2.81 \pm 0.40 \mathrm{a}$ & $2.22 \pm 0.38 \mathrm{a}$ & $1.11 \pm 0.23 \mathrm{a}$ & $6.14 \pm 1.05 \mathrm{a}$ \\
Site 4 & $1.69 \pm 0.32 \mathrm{a}$ & $1.34 \pm 0.28 \mathrm{a}$ & $1.30 \pm 0.26 \mathrm{a}$ & $4.33 \pm 0.79 \mathrm{a}$ \\
Mean & $2.22 \pm 0.36$ & $1.66 \pm 0.32$ & $1.13 \pm 0.24$ & $5.02 \pm 0.87$ \\
\hline
\end{tabular}

Between the columns, values assigned the same letter are not statistically different ( $p>0.05$; Duncan's test)

\subsubsection{Total carbon and $\mathrm{CO}_{2}$ equivalent stock}

The Total Carbon varies between sites. The highest value is recorded in site 3 (33.24 $\pm 4.28 \mathrm{tC} / \mathrm{ha}$ ). The analysis of variance does not show a significant difference in the Total Carbon between the four sites studied ( $F=0.03 ; P=0.508>0.05)$ (Table 13). The sequestered atmospheric $\mathrm{CO}_{2}$ stock varies between sites. The highest value is recorded in site 3 (121.99 $\pm 10.44 \mathrm{tCO}_{2}$ eq.ha- $\left.{ }^{-1}\right)$. The analysis of variance does not show a significant difference in the sequestered atmospheric $\mathrm{CO}_{2}$ stock between the four sites studied $(\mathrm{F}=0.37 ; \mathrm{P}=0.08>0.05)$ (Table 13).

Table 13. Total carbon and Atmospheric $\mathrm{CO}_{2}$ equivalent stock

\begin{tabular}{ccc}
\hline sites & Total Carbon $(\mathrm{tC} / \mathrm{ha})$ & Atmospheric $\mathrm{CO}_{2}$ equivalent stock $\left(\mathrm{tCO}_{2} \mathrm{eq} \cdot \mathrm{ha}^{-1}\right)$ \\
\hline Site 1 & $27.27 \pm 3.27 \mathrm{a}$ & $100.08 \pm 8.39 \mathrm{a}$ \\
Site 2 & $27.40 \pm 3.35 \mathrm{a}$ & $100.55 \pm 8.43 \mathrm{a}$ \\
Site 3 & $33.24 \pm 4.28 \mathrm{a}$ & $121.99 \pm 10.44 \mathrm{a}$ \\
Site 4 & $21.18 \pm 3.00 \mathrm{a}$ & $77.73 \pm 6.40 \mathrm{a}$ \\
Mean & $27.27 \pm 4.47$ & $100.08 \pm 8.41$ \\
\hline
\end{tabular}

Between the columns, values assigned the same letter are not statistically different ( $p>0.05$; Duncan's test).

\section{Discussions}

The study established allometric equations for estimating the above-ground and below-ground biomass of $B$. senegalensis in the diameter range between 5.76 and $24.80 \mathrm{~cm}$ 
with mean $(15.28 \mathrm{~cm})$. This result is not similar to those of [60] $(2.87 \pm 1.18 \mathrm{~cm})$ for B. senegalensis in Senegal. The allometric models developed vary from one compartment to another. The choice of method and mathematical model for adjusting the parameters must be considered judiciously in estimating the biomass of woody plants [37]. The leaf biomass, branch biomass, stem biomass, aboveground biomass (AGB) and belowground biomass (BGB) of individuals were fitted using the linear form of the power model. This mathematical model has been widely used in the literature for the prediction of standing biomass of woody species in Africa [11, 23, 24, 34, 37]. The sample size was 40 individuals. Indeed, the size of the sample in the development of allometric models is variable in the literature and takes into account the resources and time allocated to the study [6]. Some allometric biomass equations have been constructed from a limited number of individuals, 20 trees [62], 38 trees [63] , 17 trees [6] , 20 trees [64], 15 and 43 trees [60].

The average base wood density calculated for $B$. senegalensis in this study is $0.58 \mathrm{~g} / \mathrm{cm}^{3}$. This result is similar to those of [65] reported an average value of $0.58 \mathrm{~g} / \mathrm{cm}^{3}$ for 129 trees of Aglaia argentea in South-East Asia (tropical), [65] reported an average value of $0.58 \mathrm{~g} / \mathrm{cm}^{3}$ for 43 trees of Aglaia cucullata in South-East Asia (tropical), [65] reported an average value of $0.58 \mathrm{~g} / \mathrm{cm}^{3}$ for 16 trees of Aglaia lawii in South-East Asia (tropical).This result is not similar to those of [66] $\left(0.50 \mathrm{~g} / \mathrm{cm}^{3}\right)$ for Anacardium occidentale in Benin and [67] $\left(0.52 \mathrm{~g} / \mathrm{cm}^{3}\right)$ for Mangifera indica in tropical Africa. The wood density in this study is lower than the values reported for Tectona grandis plantations $\left(0.70 \mathrm{~g} / \mathrm{cm}^{3}\right)$ by [80]. In addition, [68] reported an average value of $0.54 \mathrm{~g} / \mathrm{cm}^{3}$ from 123 species in the tropical forest of Panama and [19] reported an average value of $0.60 \mathrm{~g} / \mathrm{cm}^{3}$ for 470 species from tropical America. The differences between the estimates obtained in this study and the values in the database suggest that the wood density from the databases may introduce errors in the biomass estimates. The wood density from field measurements can therefore greatly improve the precision of allometric equations compared to using estimates from the literature.

Indeed, power models generally remain extrapolable with good reliability because they are based on a fractal allometric model which is invariant at all scales [16]; which explains their wide use in biomass prediction equations for the benefit of logarithmic or polynomial models. The logarithmic transformation of the variables carried out in this study remains necessary to reduce the deviations that may exist in a real environment, and to satisfy the conditions of normality and homoscedasticity of the residuals [21]. The precision of the measurement of the explanatory variables is very decisive in the development of allometric equations [16]. DBH can be easily measured in the field with greater accuracy than other dendrometric parameters. In addition, this variable is always available in the inventory data. Numerous studies have also shown that DBH is the explanatory variable most commonly used for predicting the biomass of different compartments of woody species [10, 11, 36, 69].

However, the use of this variable alone did not allow an optimal prediction of the biomass of leaves and branches. The incorporation of total height and wood density was therefore necessary to improve the quality of prediction of the biomass of leaves and branches of B. senegalensis in the zone studies. Some authors believe that the use of DBH alone as an explanatory variable would lead to an increase in the predicted biomass [21, 36]. Previous studies have shown that incorporating height as a second variable improves the prediction performance of elaborate equations [10, 26, 36, 70] and has the advantage of increasing the potential of applicability of the equations to different sites [71]. Biomass prediction models vary according to different tree compartments. The results of these studies are similar to those obtained by $[11,32,37,71,72]$ who showed a variation in allometric equations depending on the parts of the tree. In this study, the use of this variable DBH accurately predicted the AGB and BGB. Stem biomass were better predicted with $\mathrm{D}^{2}$ $\times \mathrm{h}$. The leaves and branches biomasses were better predicted with $\mathrm{D}^{2} \times \mathrm{H} \times \mathrm{Q}$.

The logarithmic CF is a simple and straightforward statistical tool for eliminating systematic biases produced by converting the estimated logarithmic value to the original 
untransformed scale [6]. However, previous studies indicated that CF are generally small compared to the variation generated by the biomass estimate and therefore can be omitted [34]. In the present study, the CF values for all component biomass equations were relatively low. Therefore, our results indicate that few errors were introduced when using the logarithmic transformation to fit allometric equations to biomass data.

The ratio established in our study is in line with other results found in the literature such as those of [34]. We did not find results for B. senegalensis in particular, but for woody plants in general, [10] determined a ratio of 0.28 which is close to the value found in our study. The small difference observed could be due, on the one hand, to the architectural forms [6] between the species used in this study and those studied by [6] and on the other hand, to the environmental conditions which are different in the two studies. The calculated root / stems ratio (R: S), for all samples of B. senegalensis destroyed had the overall mean of 0.24 , for all diameter classes. These results are slightly low, comparable to those reported by [52] where R:S of 0.4 but higher than that of [73] where R: $S$ of 0.18 . However, these differences could have been attributed by site conditions, wood properties and management regimes.

The highest density was recorded in site 4 (535 \pm 41.85 individuals/ha). This high value would reflect appreciable regeneration within the stands. Indeed, the importance of regeneration in the plots studied is the fact that it promotes land protection by preventing rainwater from having a beating effect through foliage and root systems [74]. This result is superior to those [60] in B. senegalensis (42 $\pm 7.3 \mathrm{ind} / \mathrm{ha})$ and S. birrea $(6.1 \pm 3.4 \mathrm{ind} / \mathrm{ha})$, [75] in Gmelina arborea stands (sites $2=182 \pm 4.57$ individuals/ha and site $3=98 \pm 2.01$ individuals/ha), [73] in Cashew plantation (168 \pm 22.65 individuals/ha). The difference in density of the site studied with the other authors could be related to the ecological characteristics of the study environments, Montag including soil types, topography, climate, and cover. These results are also superior to those of [76] who reported average TOF tree density of 156 individuals/ha under communal tenure, [77] who studied TOF in Mali reported less. They came with low densities of 8-20 stems/ha in village fields that had been cultivated and from [78] who reported a higher tree density of 250 individuals/ha in forestry operations in Kenya. The higher value of basal area observed in the site 3 (10.88 \pm $2.62 \mathrm{~m}^{2} / \mathrm{ha}$ ). The highest basal area in the site 3 indicated the large tree specimens. Among the species of its undergrowth, some have a high shade rate. This may explain the high proportion of species that can provide shade in any season. These results are not close to those $[4,5,74]$. Variation in stand and basal area can be caused by a number of factors such as site productivity and silvicultural management.

The highest aboveground carbon was recorded at site $3(9.01 \pm 0.50 \mathrm{tC} / \mathrm{ha})$. Several factors could explain the spatial variability of carbon stocks recorded in the different site studied. [74] also point out that structural variables explain more of the spatial variation of biomass in tropical African forests. In fact, air carbon stock tends to increase with the increase of certain structural parameters such as basal area [79]. Then it may be noted that the most significant differences between carbon stocks between the studied orchards could lie in the importance of their basal areas and their resources dbh. The highest belowground carbon was recorded at site $3(7.11 \pm 0.35 \mathrm{tC} / \mathrm{ha})$. The main change factors agroforestry soil carbon stocks are the climate, the dominant species, in connection with the type of humus, and qualitative characteristics (pedogenetic type) and quantitative soil (clay content and soil depth) [74,85].

The litter carbon varies from $0.50 \pm 0.02-0.95 \pm 0.04 \mathrm{tC} / \mathrm{ha}$ with a higher value in site 3 . This variation could be explained by main reasons: because the litter in the site 3 comes in addition to crops, timber left standing, which adjoins the latter and the resulting wasteland debroussaged above its set up. 
The herbaceous carbon varies from $1.05 \pm 0.28-1.86 \pm 0.20 \mathrm{tC} / \mathrm{ha}$. This is explained by the fact that the closure of the forest negatively influences the carbon reservoir in the stratum herbaceous [7]. Thus, forest dynamics increasing carbon stocks in the tree and shrub layer at the expense of the herbaceous stratum [5].

The dead wood carbon vary from $3.03 \pm 0.40-8.98 \pm 0.44 \mathrm{tC} /$ ha with a higher value in site 3. The differences in carbon stocks in dead wood could explain rated by [4] who point out that carbon stocks in dead wood vary between sites and study methods. The reason site 4 store more carbon in this component is certainly due to the fact that farmers have very little involvement in this type of system.

The Soil Organic Carbon Stock vary from $4.33 \pm 0.79-6.14 \pm 1.05$ tC/ha. The carbon storage dynamics in agroforestry soil depends on changes in land use (deforestation, afforestation, etc.), climate and silvicultural practices mineralisatry increasing the activity of microorganisms in the soil (plowing, drainage, fertilization)[7, 85].

The highest total carbon was recorded in site $3(33.24 \pm 4.28 \mathrm{tC} / \mathrm{ha})$. These values are within the range reported in forest farms in the Philippines by [81] where the carbon figures ranged from $0.98 \mathrm{tC} /$ ha to $63.94 \mathrm{tC} / \mathrm{ha}$, but are not within the range reported in the three agroforestry systems by [82] where the net carbon accumulation figures ranged from 17 to $18 \mathrm{tC} /$ ha. The site 3 are great sinks of $\mathrm{CO}_{2}\left(\left(121.99 \pm 10.44 \mathrm{tCO}_{2} \mathrm{eq} \cdot \mathrm{ha}^{-1}\right)\right.$.), this explains the absence of anthropogenic emissions of greenhouse gas effects [85].

\section{Conclusions}

This study shows that the allocation of tree biomass varies depending on the compartment of B. senegalensis in the North region of Cameroon. Power-type allometric models fit well to the above-ground and below-ground biomass of the different compartments of $B$. senegalensis. The study also highlighted the specificity of allometric equations according to the parts of the tree. DBH accurately predicted the AGB and BGB of B. senegalensis. Stem biomass were better predicted with $\left(\mathrm{D}^{2} \times \mathrm{h}\right)$ of $B$. senegalensis. The leaves and branches biomasses were better predicted with $\left(\mathrm{D}^{2} \times \mathrm{H} \times \mathrm{Q}\right)$ of $B$. senegalensis. All the models developed have a fairly good predictive capacity with regard to the small differences observed between the values observed and those predicted. The established allometric models can be used to estimate the biomass of $B$. senegalensis by component under similar environmental conditions. Density ranged between $128 \pm 10.65-535 \pm 41.85$ individuals/ha; Basal area between $2.74 \pm 0.35-10.88 \pm 2.62 \mathrm{~m}^{2} / \mathrm{ha}$; Aboveground carbon ranged between $7.09 \pm 0.42-9.01 \pm 0.50 \mathrm{tC} / \mathrm{ha}$; Belowground carbon ranged between $4.37 \pm 0.26-7.11 \pm 0.35$ $\mathrm{tC} / \mathrm{ha}$; litter carbon ranged between $0.50 \pm 0.02-0.95 \pm 0.04 \mathrm{tC} / \mathrm{ha}$; herbaceous carbon ranged between $1.05 \pm 0.28-1.86 \pm 0.20 \mathrm{tC} / \mathrm{ha}$; dead wood carbon ranged between $3.03 \pm$ $0.40-8.98 \pm 0.44$ tC/ha; Soil Organic Carbon Stock varies between4.33 $\pm 0.79-6.14 \pm 1.05$ tC/ha; Total carbon were 33.24 $\pm 4.28 ; 27.40 \pm 3.35 ; 27.27 \pm 3.27$ and $21.18 \pm 3.00 \mathrm{tC} /$ ha in site 3 , site 2 , site 1 and site 4 respectively. This makes of the $B$. senegalensis contributory lungs to mitigate the mitigations of climatic disturbances. Finally, these results are also an important economic, ecological and dynamic informative value to serve as a basis for guiding any program of action aimed at the conservation and sustainable management of this species. It is recommended that the Sudano-Sahelian savannah stand management policy encourage the use of marginal or already degraded lands for the establishment of $B$. senegalensis in order to reduce the pressure on the areas better supplied with trees.

Supplementary Materials: Not Applicable.

Data Availability Statement: Not Applicable.

\section{Acknowledgements}

We would like to thank all the referees whose contributions have been very important for the improvement of this manuscript. 


\section{Conflict of Interest}

The author declares that there is no conflict of interest regarding the publication of this manuscript.

Author Contributions: Conceptualization, D.V.A. and N.N.V.; methodology, D.V.A, D.C.C.; B.T.A.V and M.G.; software, B.T.A.V.; validation, N.N.V., D.V.A and L.Z.; formal analysis, D.V.A.; investigation, L.Z and D.C.C..; writing-original draft preparation, D.V.A and M.G.; writing-review and editing, B.T.A.V.; D.C.C and M.G.; visualization, L.Z..; supervision, N.N.V and B.T.A.V. All authors have read and agreed to the published version of the manuscript.

Funding: This research received no external funding.

\section{References}

[1] FAO. Global Forest Resources Assessment 2020: Main report. Rome. 2020, 184 p. https :// doi. org/ 10.4 060/ ca 9825en.

[2] Mendoza-Ponce A.; Corona-Núñez R.; Kraxner F.; Leduc S.; Patrizio P. Identifying effects of land use cover changes and climate change on terrestrial ecosystems and carbon stocks in Mexico. Global Environ. Change. 2018, 53:12-23.

[3] Mendoza-Ponce A.; Corona-Núñez R.; Galicia L.; Kraxner F. Identifying Hotspots of Land Use Cover Change under Socioeconomic and Climate Change Scenarios in Mexico. Ambio. 2019, 48:336-349.

[4] Awé D.V.; Noiha N.V.; Zapfack L. Carbon management for savannah ecosystems in Central Africa: a case study from Cameroon. Inter J Low-Carbon Tech . 2021, 00:1-9. https://doi.org/10.1093/ijlct/ctab050.

[5] Awé D.V.; Noiha N.V.; Nyeck B.; Vroh B.T.A.; Zapfack L . Carbon storage in cashew plantations in Central Africa: case of Cameroon. Carbon Management. 2021, 12( 1):25-35. https://doi: 10.1 080/ 17583004 .2020.1858682.

[6] Tchindebe A.; Ibrahima A.; Tchobsala; Mohamadou L.M.A. Allometric Equations for Predicting Biomass of Daniellia oliveri (Rolfe) Hutch. \& Dalz. Stands in the Sudano-Guinea Savannahs of Ngaoundere, Cameroon. Ecol Evol Biol. $2019,4(2): 15-22$.

[7] Awé D.V.; Noiha N.V.; Alaam I.F.; Tengomo D.C.V.; Mbang P.; Zapfack L. Dynamics of soil organic carbon stock under different types of savannah agrosystems in the Sudano-Sahelian zone of Cameroon. Eurasian Journal of Soil Science. 2021, 10( 1):51-60. https://doi: 10.18393/ejss.809272.

[8] Liu J.; Jian N.I. Comparison of general allometric equations of biomass estimation for major tree species types in China. Quaternary Sciences. 2021, 41(4):1169-1180. https://doi: 10.11928/j.issn.1001-7410 .202 1.04.23.

[9] Gould S.J. Allometry and size in ontogeny and phylogeny. Biological Reviews. 1966, 41(4):587-638.

[10] Picard N.; Boyemba B.F.; Rossi V. Reducing the error in biomass estimates strongly depends on model selection. Annals of Forest Science. 2015, 72(6): 811-823.

[11] Henry M.; Picard N.; Trotta C.; Manlay R.J.; Valentini R.; Bernoux M.; Saint-André L. Estimating tree biomass of sub-Saharan African forests: a review of available allometric equations. Silva Fennica. 2011, 45(3B): 477-569.

[12] Djomo N.A. Forsest Ecosystem: measurement and modelling of biomass and carbon. IFED Publishing, Kingston. 2015b, 423p.

[13] Djomo N.A.; Chimi D.C. Tree allometry for estimation of above, below and total biomass in a tropical moist forest: Case study with application to remote sensing. Forest Ecology and Management. 2017, 391: 184-193.

[14] Ibrahima A. ; Schmidt P. ; Ketner P. ; Mohren G.J.M. Phytomasse et cycle des nutriments dans le foret tropical dense humide du Sud Cameroun. The Tropenbos Cameroon Programme, Yaoundé. 2002, 100 p.

[15] Brown S.; Gillespie A.; Lugo A.E. Biomass estimation methods for tropical forests with applications to forest inventory data. Forest Sciences. 1989, 35: 881-902.

[16] Picard N.; Saint-André L.; Henry M. Manuel de construction d'équations allométriques pour l'estimation du volume et la biomasse des arbres: de la mesure de terrain à la prédiction. CIRAD/FAO, Montpellier/Rome. 2012, $207 \mathrm{p}$.

[17] Brown S.; Lugo A.E. Biomass of tropical forests: A new estimate bases on forest volumes. Science. 1984, 223: 1290-1293.

[18] Brown S.; Lugo A. E. Above-ground biomass estimates for tropical moist forests of the Brazilian Amazon. Interciencia. 1992, 17: $8-18$.

[19] Brown S. Estimating biomass and biomass change of tropical forests: a primer. FAO Forestry Paper, Rome. 1997, 134 p.

[20] Brown S. ; Pearson T. Exploration du potentiel de séquestration du carbone dans lesforêts classées de la République de Guinée. Winrock International, Nairobi. 2005, 39p.

[21] Chave J.; Andalo C.; Brown S.; Cairns M.A.; Chambers J.Q.; Eamus D.; Fölster H.; Fromard F.; Higuchi N.; Kira T.; Lescure J.P.; Nelson B.W.; Ogawa H.; Puig H.; Riéra B.; Yamakura T. Tree allometry and improved estimation of carbon stocks and balance in tropical forests. Oecologia. 2005, 145:87-99.

[22] Djomo A.N.; Ibrahima A.; Saborowski J.; Gravenhorst G. Allometric equations for biomass estimations in Cameroon and pan moist tropical equations including biomass data from Africa. Forest Ecology and Management. 2010, 260: 1873-1885.

[23] Djomo N.A.; Picard N.; Fayolle A.; Henry M.; Ngomanda A.; Ploton P.; McLellan J.; Saborowski J.; Adamou I.; Lejeune P. Tree allometry for estimation of carbon stocks in African tropical forests. Forestry. 2016, 1-10.

[24] Fayolle A. ; Doucet J-L. ; Gillet J-F. ; Bourland N. ; Lejeune P. Tree allometry in Central Africa: Testing the validity of pantropical multi-species allometric equations for estimating biomass and carbon stocks. Forest Ecology and Management. $2013,305: 29-37$.

[25] Fayolle A.; Ngomanda A.; Mbasi M.; Barbier N.; Bocko Y.; Boyemba F.; Couteron P.; Fonton N.; Kamdem N.; Katembo J.; Kondaoule H.J.; Loumeto J.; Maïdou H.; Mankou G.; Mengui T.; Mofack G.II.; Moundounga C.; Moundounga Q.; Nguimbous L.; 
Nchama N. N.; Obiang D.; Ondo M. A.F.; Picard N.; Rossi V.; Senguela Y.P.; Sonké B.; Viard L.; Yongo O.D.; Zapfack L.; Medjibe V.P. A regional allometry for the Congo basin forests based on the largest ever destructive sampling. Forest Ecology and Management. 2018, 430: 228-240.

[26] Ngomanda A.; Obiang E.L.N.; Lebamba J.; Mavouroulou M.Q.; Gomat H.; Mankou S.G.; Loumeto J.; Iponga M.D.; Ditsouga K.F.; Koumba Z.R.; Bobé B.H.K.; Okouyi M.C.; Nyangadouma R.; Lépengué N.; Mbatchi B.; Picard N. Site-specific versus pantropical allometric equations: Which option to estimate the biomass of a moist central African forest? Forest Ecology and Management. 2014, 312: 1-9.

[27] Konare D. Allometric Equations for the Evaluation of Leaf Biomass of Three Woody Forage Species. Case of Afzelia Africana, Ficus Gnaphalocarpa and Pterocarpus Erinaceus, Natural Routes of the Kéniéba Circle in Southwest Mali. Revue Africaine des Sciences Sociales et de la Sante Publique. 2019,1:29-52.

[28] Ploton P. ; Barbier N. ; Momo T.S. ; Réjou-Méchain M. ; Boyemba B.F. ; Chuyong G. ; Dauby G. ; Droissart V. ; Fayolle A. ; Goodman R.C. ; Henry M. ; Kamdem N.G. ; Katembo M. J. ; Kenfack D. ; Libalah M. ; Ngomanda A. ; Rossi V. ; Sonké B. ; Texiern N. ; Thomas D. ; Zebaze D. ; Couteron P. ; Berger U. ; Pélissier R. Closing a gap in tropical forest biomass estimation: accounting for crown mass variation in pantropical allometries. Biogeosciences. 2016, 13: 1571-1585.

[29] Henry M., Besnard A., Asante W.A., Eshun J., Adu-Bredu S., Valentini R., Bernoux M. \& Saint-André L. Wood density, phytomass variations within and among trees, and allometric equations in a tropical rainforest of Africa. Forest Ecology and Management. 2010, 260: 1375-1388.

[30] Chave J.; Rejou-Mechain M.; Burquez A.; Chidumayo E.; Colgan S. M.; Delitti B.C.W.; Duque A.; Eid T.; Fearnside M.P.; Goodman C.R.; Matieu H.; Martinez-Yrizar A.; Mugasha A.W.; Muller-Landau C.H.; Mencuccini M.; Nelson W.B.; Ngomanda A.; Nogueira M.E.; Ortiz-Malavassi E.; Pelissier R.; Ploton P.; Ryan M.C.; Juan G.; Saldarriaga G.J.; Vieilledent G. Improved allometric models to estimate the aboveground biomass of tropical. Global Change Biology. , 2014, 10: 1-48.

[31] Segura M.A. ; Luis M.A.; Hernán J.A. Allometric models to estimate aboveground biomass of small trees in wet tropical forests of colombian pacific area. Rev. Árvore. 2018,42(2):1806-9088. Available:http://dx.doi.org/10.1590/1806-90882018000200009.

[32] Taeroe A.; Nord-Larsen T.; Stupak I.; Raulund-Rasmussen K. Allometric Biomass, Biomass Expansion Factor and Wood Density Models for the OP42 Hybrid Poplar in Southern Scandinavia. Bioenerg. Res. 2015, 8:1332-1343. https://doi: 10.1007/s12155-0159592-3.

[33] Mugasha W.A.; Mwakalukwa E.E.; Luoga E.; Malimbwi R.E.; Zahabu E.; Silayo D.S.; Sola G.; Crete P.; Henry M.; Kashindye A. Allometric Models for Estimating Tree Volume and Aboveground Biomass in Lowland Forests of Tanzania. International Journal of Forestry Research. 2016,(4):1-13. https://doi: 10.1155 /2016/8076271.

[34] Aabeyir R.; Adu-Bredu S.; Agyare W.A.; Weir M.J.C. Allometric models for estimating aboveground biomass in the tropical woodlands of Ghana, West Africa. Forest Ecosystems. 2020, 7:41. Available: https://doi.org/10.1186/s40663-020-00250-3.

[35] Mukuralinda A.; Kuyah S.; Ruzibiza M.; Ndoli A.; Nabahungu N.L.; Muthuri C. Allometric equations, wood density and partitioning of aboveground biomass in the arboretum of Ruhande, Rwanda. Trees, Forests and People. 2021, 3:100050. https://doi.org/10.10 16/j.tfp.2020.100050.

[36] Ganamé M.; Bayen P.; Dimobe K.; Ouédraogo I.; Thiombiano A. Aboveground biomass allocation, additive biomass and carbon sequestration models for Pterocarpus erinaceus Poir. in Burkina Faso. Heliyon. 2020, 6. https://doi.org/10.1016/j.heliyon.2020.e03805.

[37] Ganamé M.; Bayena P.; Ouédraogo I.; Balima L.H.; Thiombiano A. Allometric models for improving aboveground biomass estimates in West African savanna ecosystems. Trees, Forests and People. 2021, $4: 100077$.

[38] Youkhana A.H.; Ogoshi R.M.; Kiniry J.R.; Meki M.N.; Nakahata M.H.; Crow S.E. Allometric models for predicting aboveground biomass and carbon stock of tropical perennial C4 grasses in Hawaii. Front. Plant Sci. 2017,8:650.

[39] Ekoungoulou R. ; Liu X. ; Loumeto J. ; Ifo S.A. Above-and belowground biomass allometrics for carbon stocks estimation in secondary forest of Congo. J. Environ. Sci. Toxicol. Food Technol. 2014, 8:9-20.

[40] Fard M.E.; Heshmati A.H. Predication of biomass of three perennial range grasses using dimensional analysis. Middle East J. Sci. Res. 2014, 21:1520-1525.doi:10.5829/idosi.mejsr.2014.21.09.21702.

[41] Arbonnier M. Trees, shrubs and lianas of West African dry zones. CIRAD, Margraf Publishers Gmbh, MNHN, Paris, France. 2004, 573 pp.

[42] Kers L.E. Capparidaceae. In: Edwards, S., Mesfin Tadesse, Demissew Sebsebe \& Hedberg, I. (Editors). Flora of Ethiopia and Eritrea. Volume 2,part 1. Magnoliaceae to Flacourtiaceae. The National Herbarium, Addis Ababa University, Addis Ababa, Ethiopia and Department of Systematic Botany,Uppsala University, Uppsala, Sweden. , 2000,74-120.

[43] Kers L.E. Capparidaceae. Flore du Cameroun. Volume 29. Muséum National d'Histoire Naturelle, Paris, France.1986, 141 pp.

[44] Rabiou H. ; Inoussa M.M. ; Yacoubou B. ; Diouf A. ; Boubacar K.M. ; Mahamane A. ; Saidou I.S. ; Saadou M. ; Lykke A.M. Structure de la population de Boscia senegalensis (Pers) Lam. ex Poir. suivant la toposéquence dans la commune de Simiri (Niger). Journal of Animal EPlant Sciences. 2014, 23 (3): 3657-3669.

[45] Belem O.M.; Yameogo J.; Ouédraogo S.; Nabaloum M. Étude ethnobotanique de Boscia senegalensis (Pers.) Lam (Capparaceae) dans le Département de Banh, Province du Loroum, au Nord du Burkina Faso. Journal of Animal E Plant Sciences. 2017, 34(1): 5390-5403: ISSN 2071-7024.14 P. 
[46] Rabiou M.M. ; Sabo H. ; Mella T. M. ; Sani M. S. M. ; Sadou H. ; Saadou M. ; Amoukou I. ; Idrissa H. ; Durst B. Composition en acides aminés des graines de Boscia senegalensis issues de différentes méthodes de traitements traditionnelles au Niger.European Scientific Journal. 2019, 15(6): 1857-7881.

[47] Arbonnier M. Arbres, Arbustes et Lianes des Zones Sèches d'Afrique de l'Ouest. CIRAD, MNHN, UICN : Montpellier, France. 2000, 539p.

[48] Bonnet P. ; Arbonnier M. ; Grard P. (Ed). Ligneux du Sahel Outils graphique d'identification V.1.0. Versailles : Quae, 1 Cd-Rom. 2008.

[49] Gueye M. T.; Diallo A.; Diallo Y.; Seck D.; Vercammen J.; Lognay G. Effects of MITC Released from Boscia Senegalensis as Biopesticide in Senegalese Seeds with Special Attention to Cowpea: Detection of Residues. Journal of Environment and Ecology. 2013a. doi:10.5296/jee.v4i1.3903.

[50] Gueye M.T.; Seck D.; Diallo A.; Trisman D.; Fischer C.; Barthelemy J.-P.; Wathel J.-P.; Lognay G. Development of a Performant Method for Glucocapparin Determination in Boscia senegalensis Lam Ex. Poir.: A Study of the Variability. American Journal of Analytical Chemistry. 2013b, 4:104-110.

[51] Rabiou H. ; Diouf A. ; Inoussa M. M. ; Bakasso Y. ; Saadou M. ; Mamoudou M. B. ; Idi S.S.; Laouali A.; Mahamane A. Influence de la géomorphologie sur la distribution spatiale des peuplements de Boscia senegalensis (Pers.) Lam. ex Poir. dans la commune rurale de Simiri (Ouest Niger). European Scientific Journal. 2017, 13(30) : 1857-7881.

[52] Mugasha W.A.; Eid T.; Bollandsas O.M.; Malimbwi E.; Chamshama S.A.O.; Zahabu E.; Katani J.Z. Allometric models for prediction of above- and belowground biomass of trees in the miombo woodlands of Tanzania. For Ecol Manag. 2013, 310:87-101.

[53] Nogueira EM, Nelson BW, Fearnside PM. Wood density in dense forest in central Amazonia, Brazil. For Ecol Manag. 2005, 208:261-286.

[54] ASTM. Standard Test Methods for Moisture-Density (Unit Weight) Relations of Soil-Cement Mixtures ASTM D558 / D558M 19. West Conshohocken, PA : American Standards for Testing Methods. 2019, 545.

[55] Djomo N.A.; Ngoukwa G.; Zapfack L.; Chimi D.C. Variation of wood density in tropical rainforest trees. Journal of Forests. 2017, 4(2): 16-28.

[56] Mascaro J.; Litton C.M.; Hughes F.; Uowolo A.; Schnitzer S.A. Is logarithmic transformation necessary in allometry?Ten, onehundred, one-thousand-times yes. Biological Journal of the Linnean Society. 2014,111:230-233.

[57] Akaike H. Likelihood of a model and information criteria. J.Econ. 1981, 16:3-14.

[58] Walkley A.; Black C.A. An examination of the degt jareff method for determining soil organic matter anda proposal modification of the chromic acid titration method. Soil Science.1934, 37:29-38.

[59] AFNOR. Qualité du sol et Dosage du carbone organique par oxydation sulfochromique ou au bicarbonate de potassium (NF ISO 14235). 1998, 4.

[60] Talla R.; Sagna M.B.; Diallo M.D.; Diallo A.; Ndiaye D.; Sarr O.; Guisse A. Development of Allometric Models for Estimating the Biomass of Sclerocarya birrea (A.Rich) Hoscht and Boscia senegalensis (Pers.) Lam. ex Poir. Open Journal of Ecology. 2020, 10:571-584. https://doi.org/10.4236/oje.2020.108035.

[61] Bazezew M.; Soromessa T.; Bayable E. Carbon stock in Adaba-Dodola community forest of Danaba District, West-Arsi zone of Oromia Region, Ethiopia: An implication for climate change mitigation. Journal of Ecology and The Natural Environment. 2015,7(1):14-22.

[62] Mbow C.; Verstraete M.M.; Sambou B.; Diaw A.T.; Neufeldt H. Allometric Models for Aboveground Biomass in Dry Savanna Trees of the Sudan and Sudan-Guinean Ecosystems of Southern Senegal. Journal of Forest Research. 2013, 19:340-347. https://doi.org/10.1007/s10310-013-0414-1.

[63] Thiam S. ; Sambou B. ; Mbow C. ; Guisse A. Élaboration de modèles allométriques d'Acacia Sénégal L. Willd pour l'analyse du carbone ligneux en milieu sahélien : cas de la zone sylvopastorale au Sénégal. Afrique SCIENCE. 2014, 10(3) :304-315.

[64] Tchindebe A.; Tchobsala; Amadou M.L.M.; Ahmadou H.; Adamou I. Species-Specific Allometric Equations for Predicting Biomass of Faidherbia albida (Del.) A. Chev. In the Sudano-sahelian Savannahs of Far-North, Cameroon. J Agri Ecol Res Inter. 2020, 21(6):33-44.

[65] Zanne A.E.; Lopez-Gonzalez G.; Coomes D.A.; Ilic J.; Jansen S.; Lewis S.L.; Miller R.B.; Swenson N.G.; Wiemann M.C.; Chave J. Global wood density database. Dryad. Identifier. 2009. http://hdl.handle.net/10255/dryad.235.

[66] Biah I. ; Guendehou S. ; Goussanou C. ; Kaire M. ; Sinsin B. A. Allometric models for estimating biomass stocks in cashew (Anacardium occidentale L.) plantation in Benin. Bulletin de la Recherche Agronomique du Bénin (BRAB). 2018, 84: 16-27.

[67] Flynn J.J.H.; Holder C.D. A Guide to Useful Woods of the World. 2nd ed. Forest Products Society, Madison. 2001.

[68] Chave J. R.; Condit S.; Lao J.P.; Caspersen R.B.; Foster S.P.; Hubbell. Spatial and temporal variation in biomass of a tropical forest: results from a large census plot in Panama. Journal of Ecology. 2003, 91: $240-252$. http://dx.doi.org/10.1046/j.13652745.2003.00757.x.

[69] Kuyah S.; Dietz J.; Muthuri C.; Jamnadass R.; Mwangi P.; Coe R.; Neufeldt H. Allometric Equations for Estimating Biomass in Agricultural Landscapes: I. Aboveground Biomass. Agriculture , Ecosystems \& Environment.2012, 158:216-224. https://doi.org/10.1016/j.agee.2012.05.011.

[70] Mensah S.; Veldtman R.; Seifert T. Allometric models for height and aboveground biomass of dominant tree species in South African Mistbelt forests. Southern Forests. 2017, 79(1):19-30. 
[71] Sawadogo L.; Savadogo P.; Tiveau D.; Dayamba S.D.; Zida D.; Nouvellet Y.; Oden P.C.; Guinko S. Allometric prediction of above-ground biomass of eleven woody treespecies in the Sudanian savanna woodland of West Africa. Journal of Forestry Research. 2010, 21:475-481.

[72] Dimobe K.; Mensah S.; Goetze D.; Ouédraogo A.; Kuyah S.; Porembski S.; Thiombiano A. Aboveground biomass partitioning and additive models for Combretum glutinosum and Terminalia laxiflora in West Africa. Biomass and Bioenergy. 2018b,115:151-159.

[73] Mlagalila H.E. Assessment of volume, biomass and carbon stock of cashew nuts trees in liwale district, Tanzania. the degree of master of science in management of natural resources for sustainable agriculture of sokoine University of Agriculture. Morogoro, Tanzania. 2016,55p.

[74] Awé D.V.; Noiha N.V.; Zapfack L.; Vroh B.T. A.; Saïdou A. Carbon Sequestration Potential and Economic Value in Agroforestry Parkland to Tectona grandis L. f. (Verbenaceae) in Central Africa: A Case Study to Department of Poli (Northern Region in Cameroon).Advances in Research. 2019, 18(5): 1-16; ISSN: 2348-0394, NLM ID: 101666096.

[75] Noiha N.V.; Zapfack L.; Pelbara P.; Awé D.V.; Tabue M.R.B. Afforestation/reforestation based on gmelina arborea (Verbenaceae) in tropical Africa: Floristic and structural analysis, carbon storage and economic value (Cameroon). Sustainability in Environment. 2018, 3(2):2470-6388.

[76] Muriga C.B.; Malimbwi R.E.; Zahabu E. Carbon Storage Potential of Trees Outside Forest under Private and Communal Tenure Regimes in Ng'iresi Village, Arumeru District, Tanzania. International Journal of science and Research. 2012, 3(10): 2319-7064.

[77] Yossi H.; Kouyaté A. M. Trees Outside Forests: Mali. In: Trees Outside Forests, Towards Better Awareness. Food and Agriculture Organization, Rome, Italy. 2002,Pp 173-179.

[78] Njuguna P. M.; Holding C.; Munyasya C. On farm woody biomass surveys A case study from Nakuru and Nyandarua districts in Kenya. International Journal of Science and Research, Nakuru, Kenya. 1998, 572pp.

[79] Awé D.V.; Noiha N.V.; Zapfack L. Carbon Storage and emission factor of Savanna ecosystems in Sudano-Sahelian zone of Cameroon. Journal of Botany Research. 2020, 2(1):60-67.

[80] Guendehou G.H.S.; Lehtonen A.; Moudachirou M.; Mäkipää R.; Sinsin B. Stem biomass and volume models of selected tropical tree species in West Africa. South Forests. 2012,74(2):77-88. http://dx.doi.org/10.2989/20702620.2012.701432.

[81] Sales E.F.; Araujo J. B. S. "Levantamento de árvores consorciadas com cafeeiros no Estado do Espírito Santo”. In Congresso Brasileiro de Agroecologia, 3, Florianópolis, , Brazil: ABA, [DC-Room]. 2005.

[82] Elverfeldt C. S.; Schwarze S.; Zeller M. Could carbon payments be a solution to deforestation? Empirical evidence from Indonesia 12th Congress of the European Association of Agricultural Economists - EAAE 2008. 2008.

[83] Eneji I.S.; Obinna O.; Azuaet. Sequestration and carbon storage potential of tropical forest reserve and trees species located within benue state of Nigeria. Journal of Geoscience and Environmental Protection. 2014, 2:157-166.

[84] Awé D.V.; Noiha N.V.; Zapfack L.; Ali A.D.; Madou C. Carbon stocks in dead wood biomass of savannah ecosystems in northern region Cameroon. J Bot Res. 2019, 2(1):60-70.

[85] Awé D.V.; Noiha N.V.; Zapfack L.; Vroh B.T.A.; Nyeck B. Vegetation Structure, Root Biomass Distribution and Soil Carbon Stock of Savannah Agrosystems in Sudano-Sahelian Zone of Cameroon. J Bot Res . 2019, 2(1):71-80.

[86] Awé D.V.; Noiha N.V.; Vroh B.T.A.; Zapfack L. Biodiversity Management under Cashew Agro-ecosystems in Central Africa: A Case Study from Cameroon. Open Journal of Agricultural Research. 2021, 1(2): 45-61. Retrieved from https://www.scipublications.com/journal/in dex. php /ojar / article /view/130.

[87] Awé D.V.; Noiha N.V.; Vroh B.T. A.; Zapfack L. Root Distribution of Four Tree Species Planted in Living Hedges according to Two Types of Soil and Three Agroforestry Technologies in the Sudano-Sahelian Zone of Cameroon. Open Journal of Agricultural Research. 2021, 1(2):74-83. Retrieved from https://www.scipubli cations.com/journal/index.php/ojar/article/view/138. 